\title{
Monocyclic Nitro-heteroaryl Nitrones with Dual Mechanism of Activation: Synthesis and Antileishmanial Activity
}

Juliana da Silva Pachecoł, Débora de Souza S. Costał, Edézio Ferreira Cunha-Júnior, Valter Viana Andrade-Neto, Alan H. Fairlamb, Susan Wyllie, Marília Oliveira Fonseca Goulart, Danyelle Santos, Thaissa L. Silva, Marina A. Alves, Paulo Roberto Ribeiro Costa ${ }^{*}$, Ayres G. Dias* and Eduardo Caio Torres-Santos*

†Equal contribution

\section{Supporting Information}

\section{TABLE OF CONTENTS}

1. Chemistry S2

2. Experimental approach for in vitro anti-leishmanial activity $\quad$ S4

3. Determination of cytotoxicity S5

4. Evaluation of Reactive Oxygen Species production S5

5. Efficacy in experimental visceral leishmaniasis S6

6. Determination of in vitro chemical stability $\quad$ S6

$\begin{array}{lll}\text { 7. Determination of } \text { in vitro aqueous solubility } & \text { S7 }\end{array}$

$\begin{array}{ll}\text { 8. Determination of in vitro stability in mice plasma } & \text { S7 }\end{array}$

9. Determination of in vitro metabolic stability in human S9 fraction

$\begin{array}{ll}\text { 10. Electrochemical Studies } & \text { S8 }\end{array}$

11. ${ }^{1} \mathrm{H},{ }^{13} \mathrm{C}, \mathrm{LC} / \mathrm{UV}$ and HRMS spetra of most active compounds $\quad$ S9

$\begin{array}{ll}\text { 12. References } & \text { S28 }\end{array}$

\section{Chemistry}

\subsection{General Information}

All reagents and solvents are commercially available and applied without further purification. ${ }^{1} \mathrm{H}$ and ${ }^{13} \mathrm{C}$ NMR raw data were collected by a Bruker AMX500 $(500 \mathrm{MHz})$ spectrometer and spectrums were exported through MestReNova software. Deuterated solvent included $\mathrm{CDCl}_{3}$, and 
as internal standard teramethylsilane. The chemical shifts $(\delta)$ are reported in parts per million (ppm) and the coupling constant (J) unit is Hz. High resolution mass spectrometry (HRMS) was obtained through an equipment Q Exactive ${ }^{\mathrm{TM}}$ Hybrid Quadrupole-Orbitrap Mass spectrometer. HPLC analyses were performed on an UltiMate 3000 UHPLC, using water and methanol as mobile phase. The purity was analyzed using an HPLC-PDA Shimadzu - LC20AD (acetonitrile/water 4:6 to methyl nitrones and acetonitrile/water 4:6 to t-butyl nitrones). Flash chromatography carried out on silica gel 100-200 mesh with newly configured eluent. Compounds $3 \mathrm{a}, 3 \mathrm{~b}$ and 4 were prepared in previous publication and $5 \mathrm{a}, 5 \mathrm{~b}, 6 \mathrm{a}, 6 \mathrm{~b}$ and 7 were acquired from commercial sources. ${ }^{9}$

\subsection{Experimental procedures}

\subsubsection{General method for N-methylnitrone preparation}

To a solution of nitroheteroaryl aldehydes $(1.0 \mathrm{mmol})$, triethylamine $(1.0 \mathrm{mmol})$ in $\mathrm{CH}_{2} \mathrm{Cl}_{2}(30$ $\mathrm{ml})$, in the presence of dry $\mathrm{Na}_{2} \mathrm{SO}_{4}(1 \mathrm{mmol})$, was added $N$-methylhydroxylamine hydrochloride $(1.0 \mathrm{mmol})$ or $\mathrm{N}$-benzylhydroxylamine hydrochloride $(2 \mathrm{mmol})$. The mixture was stirred at room temperature. The crude product was purified by column chromatography on silica gel (Petroleum ether/Ethyl acetate $=2: 8, \mathrm{v} / \mathrm{v}$ ).

\section{5-Nitrofuran-2-yl-N-methyl nitrone (1b)}

Starting from 5-nitro-2-furaldehyde $(500 \mathrm{mg}, 3.54 \mathrm{mmol})$ the mixture was stirred at room temperature for about $1 \mathrm{~h}$. After reaction, the solvent was removed under vacuum, and the residue was directly purified through flash column to afford $2 \mathrm{~b}$ as a yellow to light brown powder (yield 91\%). ${ }^{1} \mathrm{H}$ NMR $\left(500 \mathrm{MHz}, \mathrm{CDCl}_{3}\right) \delta=7.84(\mathrm{~d}, J=3.9 \mathrm{~Hz}, 1 \mathrm{H}), 7.66(\mathrm{~d}, J=0.5 \mathrm{~Hz}, 1 \mathrm{H}), 7.42(\mathrm{dd}$, $J=3.9,0.6 \mathrm{~Hz}, 1 \mathrm{H}), 3.93(\mathrm{~s}, 3 \mathrm{H}) \cdot{ }^{13} \mathrm{C} \mathrm{NMR}(126 \mathrm{MHz}, \mathrm{CDCl} 3) \delta 148.30$ (s), 124.53 (s), 116.12 (s), $113.42(\mathrm{~s}), 54.03(\mathrm{~s})$.

HRMS $\mathrm{C}_{6} \mathrm{H}_{6} \mathrm{~N}_{2} \mathrm{O}_{4}[\mathrm{M}+\mathrm{H}]^{+}$calculated $=171.04003$, observed $=171.0397$. The preparation of compound $\mathbf{2} \mathbf{b}$ was similar to this procedure.

\section{$\mathrm{CH}_{3} \mathrm{NHOH} . \mathrm{HCl}$}
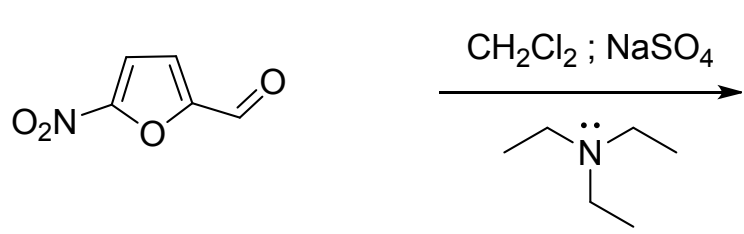<smiles>C[N+]([O-])=Cc1ccc([N+](=O)[O-])o1</smiles>

\section{5-Nitrothiophen-2-yl-N-methyl nitrone (2b)}

Starting from 5-nitro-2-thiophenecarboxaldehyde $(500.0 \mathrm{mg}, 3.17 \mathrm{mmol})$, green powder, yield 98\%. ${ }^{1} \mathrm{H}$ NMR (500 MHz, $\left.\mathrm{CDCl}_{3}\right) \delta 7.96(\mathrm{~s}, 1 \mathrm{H}), 7.91(\mathrm{~d}, \mathrm{~J}=4.5 \mathrm{~Hz}, 1 \mathrm{H}), 7.26(\mathrm{~d}, \mathrm{~J}=4.6 \mathrm{~Hz}$, 
1H), $3.94(\mathrm{~s}, 3 \mathrm{H}) .{ }^{13} \mathrm{C} \mathrm{NMR}\left(126 \mathrm{MHz}, \mathrm{CDCl}_{3}\right) \delta 137.81(\mathrm{C}), 130.20(\mathrm{CH}), 127.28(\mathrm{CH}), 126.54$ $(\mathrm{CH}), 52.32(\mathrm{CH})$.

HRMS $\mathrm{C}_{6} \mathrm{H}_{6} \mathrm{~N}_{2} \mathrm{O}_{3} \mathrm{~S}[\mathrm{M}+\mathrm{H}]^{+}$calculated $=187.01718$, observed $=187.01671$.<smiles>C/[N+]([O-])=C/c1ccc([N+](=O)[O-])s1</smiles>

\section{5-Nitrofuran-2-yl-N-benzylnitrone (1c)}

Starting from 5-nitro-2-furaldehyde $(100 \mathrm{mg}, 0,70 \mathrm{mmol})$ the mixture was stirred at room temperature for about $4 \mathrm{~h}$, yellow to light brown powder, yield $80 \%$. ${ }^{1} \mathrm{H} \mathrm{NMR}\left(500 \mathrm{MHz}, \mathrm{CDCl}_{3}\right)$ $\delta 7.81(\mathrm{~d}, \mathrm{~J}=3.8 \mathrm{~Hz}, 1 \mathrm{H}), 7.55(\mathrm{~s}, 1 \mathrm{H}), 7.43(\mathrm{~s}, 5 \mathrm{H}), 7.37(\mathrm{~d}, \mathrm{~J}=3.8 \mathrm{~Hz}, 1 \mathrm{H}), 5.06(\mathrm{~s}, 2 \mathrm{H}) .{ }^{13} \mathrm{C}$ NMR (126 MHz, $\left.\mathrm{CDCl}_{3}\right) \delta 148.50(\mathrm{~d}, \mathrm{~J}=3.5 \mathrm{~Hz}), 131.60(\mathrm{~s}), 129.93(\mathrm{~d}, \mathrm{~J}=6.6 \mathrm{~Hz}), 129.57(\mathrm{~s})$, 129.47 (d, J = 6.2 Hz), 129.11 (s), 113.75 (s), 113.20 (s), 70.94 (s).

HRMS $\mathrm{C}_{12} \mathrm{H}_{10} \mathrm{~N}_{2} \mathrm{O}_{4}[\mathrm{M}+\mathrm{H}]^{+}$calculated $=247,0713$, observed $=246,9413$.<smiles>O=[N+]([O-])c1ccc(/C=[N+](\[O-])Cc2ccccc2)o1</smiles>

\section{5-Nitrothiofuran-2-yl-N-benzyl nitrone (2c)}

Starting from 5-nitro-2-thiophenecarboxaldehyde (100 $\mathrm{mg}, 0.63 \mathrm{mmol}, 1.0$ equiv) the mixture was stirred at room temperature for about $4 \mathrm{~h}$, green powder, yield $85 \% .{ }^{1} \mathrm{HNMR}\left(500 \mathrm{MHz}, \mathrm{CDCl}_{3}\right)$ $\delta 7.88(\mathrm{~d}, \mathrm{~J}=4.6 \mathrm{~Hz}, 1 \mathrm{H}), 7.86(\mathrm{~s}, 1 \mathrm{H}), 7.44(\mathrm{~s}, 5 \mathrm{H}), 7.20(\mathrm{~d}, \mathrm{~J}=4.6 \mathrm{~Hz}, 1 \mathrm{H}), 5.13(\mathrm{~s}, 2 \mathrm{H}) .{ }^{13} \mathrm{C}$ NMR (126 MHz, $\mathrm{CDCl}_{3}$ ) $\delta 137.90$ (s), 129.83 (s), 129.53 (s), 129.38 (s), 129.06 (s), 127.27 (s), $126.71(\mathrm{~s}), 69.23(\mathrm{~s})$.

HRMS $\mathrm{C}_{12} \mathrm{H}_{10} \mathrm{~N}_{2} \mathrm{O}_{3} \mathrm{~S}[\mathrm{M}+\mathrm{H}]^{+}$calculated $=263,0485$, observed $=262,9316$.

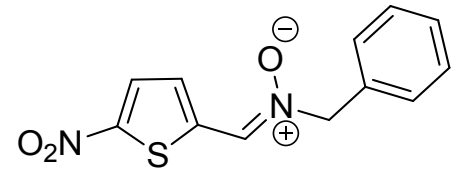

\subsubsection{General method for preparation of $N$-tert-butyl nitrones}

To a solution of nitroheteroaryl aldehydes $(1.0 \mathrm{mmol})$, triethylamine $(2.0 \mathrm{mmol})$ in $\mathrm{CH}_{2} \mathrm{Cl}_{2}(30$ $\mathrm{ml})$, in the presence of dry $\mathrm{Na}_{2} \mathrm{SO}_{4}(2 \mathrm{mmol})$, was added $N$-tert-butylhydroxylamine hydrochloride $(2 \mathrm{mmol})$. The mixture was reflux at $60^{\circ} \mathrm{C}$ for $4 \mathrm{~h}$. The crude product was purified by column chromatography on silica gel (Petroleum ether/Ethyl acetate $=7: 3, \mathrm{v} / \mathrm{v}$ ). 
Starting from 5-nitro-2-furaldehyde (100mg, 0.70mmol), yellow to light brown powder, yield $90 \% .{ }^{1} \mathrm{H}$ NMR $\left(500 \mathrm{MHz}, \mathrm{CDCl}_{3}\right){ }^{1} \mathrm{H}$ NMR $\left(400 \mathrm{MHz}, \mathrm{CDCl}_{3}\right) \delta=7.87(\mathrm{~s}, 1 \mathrm{H}), 7.84(\mathrm{~d}, J=3.9$ $\mathrm{Hz}, 1 \mathrm{H}), 7.42(\mathrm{~d}, J=3.9 \mathrm{~Hz}, 1 \mathrm{H}), 1.60(\mathrm{~s}, 9 \mathrm{H}) .{ }^{13} \mathrm{C} \mathrm{NMR}\left(126 \mathrm{MHz}, \mathrm{CDCl}_{3}\right) \delta=151.11(\mathrm{C})$, $149.44(\mathrm{C}), 119.99(\mathrm{CH}), 115.71(\mathrm{CH}), 113.66(\mathrm{CH}), 72.02(\mathrm{C}), 28.03\left(\mathrm{CH}_{3}\right)$.

HRMS $\mathrm{C}_{9} \mathrm{H}_{12} \mathrm{~N}_{2} \mathrm{O}_{4}[\mathrm{M}+\mathrm{H}]^{+}$calculated $=213.08698$, observed $=213.08654$.

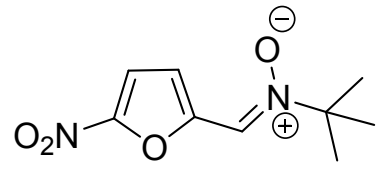

\section{5-Nitrothiophen-2-yl-N-t-butyl nitrone (2a)}

Starting from 5-nitro-2-thiophenecarboxaldehyde $(100 \mathrm{mg}, 0.63 \mathrm{mmol})$, green powder, yield $72 \% .{ }^{1} \mathrm{H}$ NMR $\left(500 \mathrm{MHz}, \mathrm{CDCl}_{3}\right) \delta=8.16(\mathrm{~s}, 1 \mathrm{H}), 7.94(\mathrm{~d}, J=4.6 \mathrm{~Hz}, 1 \mathrm{H}), 7.31(\mathrm{~d}, J=4.6 \mathrm{~Hz}$, $1 \mathrm{H}), 1.63(\mathrm{~s}, 9 \mathrm{H}) .{ }^{13} \mathrm{C} \mathrm{NMR}\left(126 \mathrm{MHz}, \mathrm{CDCl}_{3}\right) \delta=138.91(\mathrm{C}), 127.27(\mathrm{CH}), 126.51(\mathrm{CH}), 125.21$ $(\mathrm{CH}), 70.78(\mathrm{C}), 28.03\left(\mathrm{CH}_{3}\right)$.

HRMS $\mathrm{C}_{9} \mathrm{H}_{12} \mathrm{~N}_{2} \mathrm{O}_{3} \mathrm{~S}[\mathrm{M}+\mathrm{H}]^{+}$calculated $=229.06413$, observed $=229.0637$.<smiles>CC(C)(C)N([O-])C=Cc1ccc([N+](=O)[O-])s1</smiles>

\section{Experimental approach for in vitro anti-leishmanial activity}

\subsection{Antipromastigote activity on $L$. Infantum and L. amazonensis}

L. infantum (MHOM / MA / 67 / ITMAP-263) and L. amazonensis (MHOM / BR / 77 / LTB0016) were used. Promastigotes of $L$. amazonensis $\left(1 \times 10^{6}\right.$ parasites $\left./ \mathrm{mL}\right)$ grown in Schneider's Drosophila medium supplemented with fetal bovine serum (FBS) were incubated for $72 \mathrm{~h}$ with increasing concentrations of compounds $(1.56-100 \mu \mathrm{M})$ and of the reference drugs miltefosine and nifurtimox $(0,39-100 \mu \mathrm{M})$. Viability was determined by adding resazurin $(50 \mu \mathrm{M})$ per well and the fluorescence measured (560 and 590nm, excitation and emission, respectively) after $4 \mathrm{~h}$ incubation. The value corresponding to half of the maximum effective concentration $\left(\mathrm{EC}_{50}\right)$ for each curve was determined by nonlinear logarithmic regression in the GraphPad Prism 5.0 program.

\subsection{Anti-amastigote activity}

Peritoneal macrophages from BALB/c mice were collected in RPMI medium supplemented with $10 \%$ FBS, $1 \%$ glutamine and $1 \%$ pyruvate, and seeded at $1 \times 10^{6} / \mathrm{ml}$ in a 24 -well plate with coverslips and incubated at $37^{\circ} \mathrm{C}$ under a $5 \% \mathrm{CO} 2$ atmosphere for $1 \mathrm{~h}$. Non-adherent cells were 
removed by washing with pre-heated medium. Promastigotes of L. amazonensis or L. infantum were added in the proportion of 3:1 or 5:1 parasites/macrophages, respectively and the cultures were incubated for an additional 3 or $4 \mathrm{~h}$. The cell monolayers were washed three times in the case of L. amazonensis infection and 10 times when the infection was carried out with L. infantum to remove free parasites. Concentrations of the compounds corresponding to the value of twice, half and a quarter of the $\mathrm{EC}_{50}$ value in promastigotes were added and incubated for $72 \mathrm{~h}$. The slides were stained with PANOTIC according to the manufacturer's instructions. The number of intracellular amastigotes was determined by counting at least 100 cells per well, and the results were expressed in an infection index (IF), using the following formula: IF $=(\%$ infected cells $X$ number of amastigotes) / total number of macrophages. The $\mathrm{EC}_{50}$ was determined by logarithmic nonlinear regression analysis using GraphPrism 5 software.

\subsection{In vitro sensitivity on $L$. donovani NTR1 and NTR2 over-expressing cell lines}

The clonal Leishmania donovani cell line LdBOB (derived from MHOM/SD/62/1 S-CL2D) was grown as promastigotes at $26^{\circ} \mathrm{C}$ in modified M199 media. LdBOB promastigotes overexpressing NTR1(LinJ.05.0660) and NTR2 (LinJ.12.0730) were grown in the presence of nourseothricin $(100 \mathrm{mg} / \mathrm{mL})$, as previously described (Wyllie et al., 2013; Wyllie et al., 2016). To examine the effects of test compounds on growth triplicate promastigote cultures were seeded with $1 \times 10^{6}$ parasites $/ \mathrm{mL}$. Parasites were grown in $10 \mathrm{~mL}$ cultures in the presence of drug for $72 \mathrm{~h}$, after which $200 \mathrm{~mL}$ aliquots of each culture were added to 96-well plates, 50mMresazurin was added to each well and fluorescence (excitation of $528 \mathrm{~nm}$ and emission of $590 \mathrm{~nm}$ ) measured after a further $4 \mathrm{~h}$ incubation (Wyllie et al., 2016). Data were processed using GRAFIT (version 5.0.4; Erithacus software) and fitted to a 2-parameter equation, where the data are corrected for background fluorescence, to obtain the effective concentration inhibiting growth by $50 \%[y=100 /$ $\left[1+\left(\mathrm{I} / \mathrm{EC}_{50}\right)^{\mathrm{m}}\right]$. In this equation, $[\mathrm{I}]$ represents inhibitor concentration and $\mathrm{m}$ is the slope factor. Experiments were repeated at least two times, and the data is expressed as the mean plus standard deviation.

\section{Determination of cytotoxicity}

Peritoneal macrophages from BALB/c mice were plated $2 \times 10^{6} / \mathrm{mL}$ with RPMI supplemented with $10 \% \mathrm{FBS}, 1 \%$ glutamine and $1 \%$ pyruvate in 96 -well plates and incubated at $37^{\circ} \mathrm{C}$ under a $5 \% \mathrm{CO}_{2}$ atmosphere for $1 \mathrm{~h}$. Non-adherent cells were removed by washing with a complete preheated medium. The cell monolayers were incubated for $72 \mathrm{~h}$ with increasing concentrations of the compounds $(1.56-200 \mu \mathrm{M})$, nifurtimox and miltefosine $(0.39-100 \mu \mathrm{M})$. Viability was determined by adding $50 \mu \mathrm{M}$ resazurin per well and the fluorescence (560 and 590nm, excitation and emission, respectively) was measured after $4 \mathrm{~h}$ of incubation. The value corresponding to half of the maximum cytotoxic concentration $\left(\mathrm{CC}_{50}\right)$ for each curve was determined by logarithmic nonlinear regression in the GraphPad Prism 5.0 program. The Selectivity Index (SI) (ratio between $\mathrm{CC}_{50}$ for macrophages and $\mathrm{IC}_{50}$ for intracellular amastigotes) was also calculated.

\section{Evaluation of Reactive Oxygen Species production}


The production of reactive oxygen species (ROS)was evaluated according to the methodology previously used by Ribeiro et al. (2013). Intracellular levels of ROS were measured in treated and untreated cells. Briefly, $1 \times 10^{7} \mathrm{~L}$. infantum promastigotes grown in Schneider's Drosophila medium supplemented with $20 \%$ FBS were incubated at $25^{\circ} \mathrm{C}$ with concentrations of the compounds varying according to the $\mathrm{IC}_{50}$ obtained from the antipromastigote assay. Then, $20 \mu \mathrm{M}$ of 2',7'-dichlorodihydrofluorescein diacetate $\left(\mathrm{H}_{2}\right.$ DCFDA) (Molecular Probes) was added and fluorescence was monitored kinetically over $4 \mathrm{~h}$ using a spectrofluorometer at wave lengths of $485 \mathrm{~nm}$ (excitation) and 530nm (emission).

\section{Efficacy in experimental Visceral Leishmaniasis}

The effectiveness of the $\mathbf{1 b}$ was evaluated according to the methodology adapted from (CunhaJunior et al., 2016). BALB/c mice were infected intraperitoneally with $1 \times 10^{8} \mathrm{~L}$. infantum promastigotes in stationary phase. In this model, the parasite burden in liver and spleen increases in the first four weeks of infection, as published previously (Cunha-Junior et al., 2016). The infected animals were treated orally seven days after infection ( $\mathrm{n}=5 /$ dose group) once or twice a day with compound $\mathbf{1 b}$, omeprazole, miltefosine or vehicle (phosphate saline buffer) for ten consecutive days. Omeprazole $(20 \mathrm{mg} / \mathrm{kg} /$ day) was administered to the groups treated with the compound 1a one hour before. Compound 1a was administered as a suspension in the commercial adjuvant Oraplus in doses of $25,50 \mathrm{or} 100 \mathrm{mg} / \mathrm{kg} /$ day. After the tenth day of treatment, the animals infected with $L$. infantum were euthanized in a $\mathrm{CO}_{2}$ chamber, and the spleen and liver were removed aseptically, weighed and homogenized. The parasitic load was estimated in the target organs using the limiting dilution test in both experimental models.

The dose of miltefosine was calculated based on the recommended dose for humans as proposed by Reagan-Shaw, Nihal \& Ahmad (2008) Animal dose (mg / kg) $=($ Human $\mathrm{km} /$ Animal km) $\mathrm{x}$ human dose $(\mathrm{mg} / \mathrm{kg})$, where mouse $\mathrm{km}=3$, human $\mathrm{km}=37$ and human weight $=60 \mathrm{~kg}$, as recommended by the FDA (FDA, 1995).

\section{Determination of in vitro chemical stability.}

On the basis of the pharmacological data, compounds $1 \mathrm{a}$ and $1 \mathrm{~b}$ are promising for the in vivo study in Leishmannia sp. These compounds present a nitrone subunit, which may represent vulnerability to hydrolysis, leading to instability and limiting the development of these compounds as candidate drugs.

Thus, to advance the development of the nitrones as antiparasitic agents, we evaluated the chemical stability of the most promising compounds from the series, namely, $\mathbf{1 a}, \mathbf{1} \mathbf{b}, \mathbf{2} \mathbf{a}$ and $\mathbf{2 b}$, under two conditions: $\mathrm{pH} 2.0$ and 7.4, to mimic the acidic stomach and the neutral plasma environments, respectively. To this end, compounds were examined in the presence of acidic $(\mathrm{pH}$ 2) and neutral (pH 7.4) buffers under stirring for up to $240 \mathrm{~min}$ at a controlled temperature (37 $\left.{ }^{\circ} \mathrm{C}\right)$.

In the neutral medium ( $\mathrm{pH}$ 7.4), all of the compounds were stable, with less than $30 \%$ of degradation, as observed from the compound recovery percentage after $4 \mathrm{~h}$. However, in acidic buffer, all of the compounds underwent hydrolysis, although 2a showed greater stability, with a higher percentage recovery of $80 \%$ after $4 \mathrm{~h}$, and significant quantities of the compounds with a methyl group at nitrogen (1) and $\mathbf{2 b}$ ) were recovered after $30 \mathrm{~min}$. 
Two microliters $(0.01 \mathrm{mmol})$ of a concentrated solution of the compound $(40 \mathrm{mM}$ stock solution solubilized in DMSO) and $248 \mu \mathrm{L}$ of acid (0.2 M potassium chloride and $0.2 \mathrm{M} \mathrm{HCl}$; $\mathrm{pH} 2.0$ ) or neutral (phosphate dibasic, $\mathrm{pH}$ 7.4) buffer were added to a $1.5 \mathrm{~mL}$ Eppendorf microtube. The mixture was vortexed and placed in a water bath at $37^{\circ} \mathrm{C}$ under moderated stirring for 30,60 , 120 , and $240 \mathrm{~min}$. After each reaction including $0 \mathrm{~min}, 248 \mu \mathrm{L}$ of basic buffer (phosphate buffer, $\mathrm{pH}$ 8.4) was added to neutralize the $\mathrm{pH}$ of the medium in the experiments using acidic buffer. Acetonitrile $(1 \mathrm{~mL})$ was added followed by vigorous vortexing and freezing of the aqueous phase $\left(-10^{\circ} \mathrm{C}\right)$ to extract the compound. The organic phase was separated, filtered through a $0.45 \mu \mathrm{m}$ filter, and analyzed using an HPLC-PDA (acetonitrile/water 60:40) (Rodrigues at al., 2016).

\section{Determination of in vitro aqueous solubility}

The solubility experiment was based on by liquid chromatography-high resolution mass spectrometry (UHPLC-HRMS). The saturated aqueous solution (buffer 7.4) was stirred for 24 $\mathrm{h}$, and the sample was filtered through a $0.45 \mu \mathrm{m}$ filter and transferred to a vial to perform the analysis on a Q Exactive ${ }^{\mathrm{TM}}$ hybrid Quadrupolo-Orbitrap ${ }^{\mathrm{TM}}$. The solubility was determined through linear regression using graph plots, and solutions were prepared by dilutions of the original solution in methanol. The mean values were used to plot the graphs. The correlation coefficient $\left(\mathrm{R}^{2}\right)$ values were above 0.999 .

\section{Determination of in vitro plasma stability.}

The plasma stability of compounds $\mathbf{1 a}, \mathbf{1} \mathbf{b}, \mathbf{2} \mathbf{a a n d} \mathbf{2} \mathbf{b}$ was determined following the methodology adapted from Konsoula and Jung (Konsoula and Jung, 2008). The mouse plasma sample was validated using benzocaine as standard. This standard was almost completely metabolized by plasma enzymes at the time of $240 \mathrm{~min}$, resulting in the formation of the para-aminobenzoic acid (data not shown).

The in vitro plasma stability of compounds was performed using a pool of mouse plasma obtained by centrifuging heparinized blood at $2000 \mathrm{rpm}$ for $15 \mathrm{~min}$ at $4^{\circ} \mathrm{C}$. Plasma was diluted to $64 \%$ $(\mathrm{v} / \mathrm{v})$ with phosphate-buffered saline (PBS, $\mathrm{pH}=7.4$ ). The reaction was started by adding $2 \mu \mathrm{L}$ of a stock solution $2 \mathrm{ng} / \mathrm{ml}$ in DMSO of mixed sample to $98 \mu \mathrm{L}$ of plasma. The samples remained in the water bath at $37^{\circ} \mathrm{C}$ under constant agitation at 0 and $240 \mathrm{~min}$. After each reaction aliquots $(50 \mu \mathrm{L})$ withdrawn were extracted with cold methanol $(450 \mu \mathrm{L})$, followed by agitation in vortex and centrifugation at 13,000 rpm for $15 \mathrm{~min}$ at room temperature. The supernatant was dried in SpeedVac Vacuum Concentrator and then analyzed by LC/MS/MS, in the equipment Q Exactive $^{\mathrm{TM}}$ Hybrid Quadrupole-Orbitrap Mass Spectrometer, Syncronis C18 columns $(1.7 \mu \mathrm{m}$; $50 \mathrm{~mm} X 2.1 \mathrm{~mm} ; 100 \AA$ ) and performed to quantify the analyte in flow rate $300 \mu \mathrm{l} / \mathrm{min}$ with $8 \mu \mathrm{L}$ injection. Data were acquired by Trace Finder software, version 4.0, using as standard benzocaine. Results are represented as the percentage of the compound remaining.

\section{Determination of in vitro human S9 fraction stability.}

Screening studies for metabolic stability were performed with human S9 fraction, and degradation at $0,15,30$ and $60 \mathrm{~min}$ in the presence of cofactor was measured by LC/MS/MS analysis. Experiments were conducted in triplicate. 
Pooled human liver S9 fractions (Thermo Fisher Scientific), NADPH (Sigma), sodium dihydrogen orthophosphate (Merck), disodium hydrogen orthophosphate (Merck), acetonitrile (Merck) and DMSO (Sigma) used in the study. Stock solution (100 mM) of test compound was prepared in DMSO due to low solubility and from it work solutions of $50 \mathrm{ng} / \mathrm{ml}$ and from these 2 $\mathrm{ng} / \mathrm{ml}$ were prepared in acetonitrile. NADPH solution (cofactor) was prepared to produce final NADPH concentration of $10 \mathrm{mM}$. The reaction mixture containing $183 \mu \mathrm{l}$ of sodium phosphate buffer (100 mM, pH 7.4) and $5 \mu$ of human S9 fraction (final protein concentration $0,5 \mathrm{mg} / \mathrm{mL}$ ) was pre-incubate at $37^{\circ} \mathrm{C}$ for $5 \mathrm{~min}$. The reactions were initiated with the addition of $20 \mu \mathrm{L} 10$ $\mathrm{mM} \mathrm{NADPH}$ and incubated up to $60 \mathrm{~min}$ at $37^{\circ} \mathrm{C}$ with gentle agitation. Reactions were terminated by the addition of $200 \mu \mathrm{L}$ col methanol, vortexed, and centrifuged at approximately $10000 \mathrm{rpm}$ for $5 \mathrm{~min}$. The resulting supernatant was transferred to a microtube containing $100 \mathrm{ng} / \mathrm{ml}$ of internal standard. Positive control samples were prepared as described above, except the test compound was replaced with the known substrate phenacetin. The analyte/internal standard peak area ratio was determined in each sample by LC/MS/MS. The results are expressed as percent drug metabolized based on the levels at the start of the incubation ( 0 min sample).

\section{Electrochemical Studies}

The electrochemical studies of the present nitrones (1a, 1b, 2a, 2b, 4) and some of the corresponding aldehydes $(\mathbf{5 a}, \mathbf{7})$, on glassy carbon electrode (GCE) were performed to evaluate their electrochemical behaviors, in aprotic medium (DMF $\left.+\mathrm{TBAPF}_{6} 0.1 \mathrm{~mol} \mathrm{~L}^{-1}\right)$, at room temperature $\left(25 \pm 2{ }^{\circ} \mathrm{C}\right)$. Cyclic voltammetry (CV) experiments were performed with a conventional undivided three-electrode cell, using an Autolab PGSTAT-30 potentiostat (Echo Chemie, Utrecht, the Netherlands), coupled to a microcomputer, interfaced by a GPES 4.9 and NOVA softwares. The working electrode was a glassy carbon electrode (GCE) $(\mathrm{d}=3 \mathrm{~mm})$, the counter electrode was a Pt wire, and the reference electrode was an $\mathrm{Ag}|\mathrm{AgCl}| \mathrm{Cl}^{-}(\mathrm{KCl}, 3 \mathrm{M})$. GCE was cleaned up by polishing with alumina on a polishing felt (BAS polishing kit. Each compound $\left(1 \times 10^{-3} \mathrm{~mol} \mathrm{~L}^{-1}\right)$ was added to the supporting electrolyte, and the solution was deoxygenated with argon, before the CV measurements. A flux of argon was kept over the solution for the experiments. To compare with the literature, Eredox [(EpIc $+E \mathrm{pIa}) / 2]$ values were measured. To compare with the literature, the values were referred in relation to the Normal Hydrogen Electrode (NHE). Thus, we added $0.210 \mathrm{~V}$ to the experimental redox potentials $v$ s. $\mathrm{Ag}|\mathrm{AgCl}| \mathrm{Cl}^{-}(\mathrm{KCl}, 3$ $\mathrm{M})$, reported in figure 1, vs. $\mathrm{Ag}|\mathrm{AgCl}| \mathrm{Cl}^{-}(\mathrm{KCl}, 3 \mathrm{M})$.

Figure 1. Cyclic voltammetry $(\mathrm{CV})$ of $\mathrm{LQB}-484$, in $\mathrm{DMF}+\mathrm{TBAPF}_{6}\left(0.1 \mathrm{~mol} \mathrm{~L}^{-1}\right)$. Glassy carbon electrode, cathodic direction, $v=100 \mathrm{mVs}^{-1}$. (A) Successive CV; black line - scan 1 and red line - scan 2. (B) Several inversion potentials in the CV. 


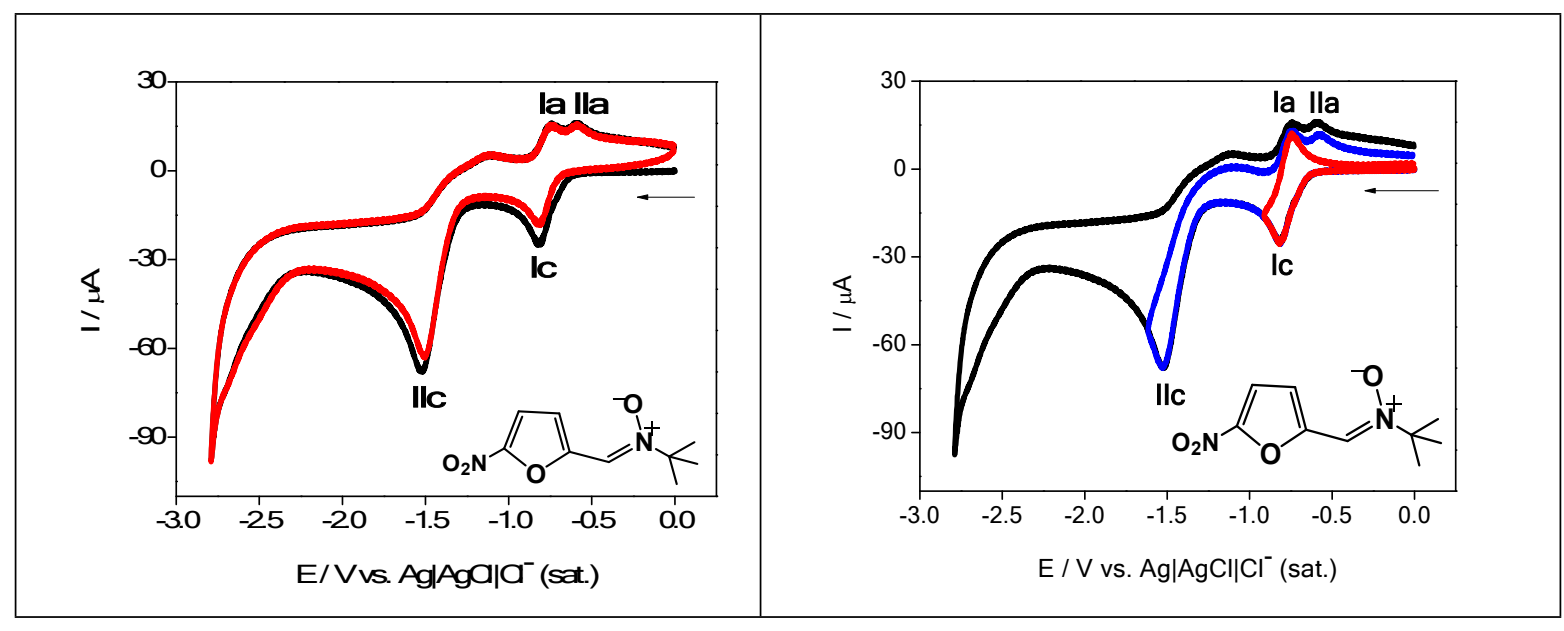

11. ${ }^{1} \mathrm{H},{ }^{13} \mathrm{C}, \mathrm{LC} / \mathrm{UV}$ and HRMS spetra of most active compounds

1. ${ }^{1} \mathrm{H} \mathrm{NMR}\left(500 \mathrm{Mhz}, \mathrm{CDCl}_{3}\right) \mathbf{1 b}$

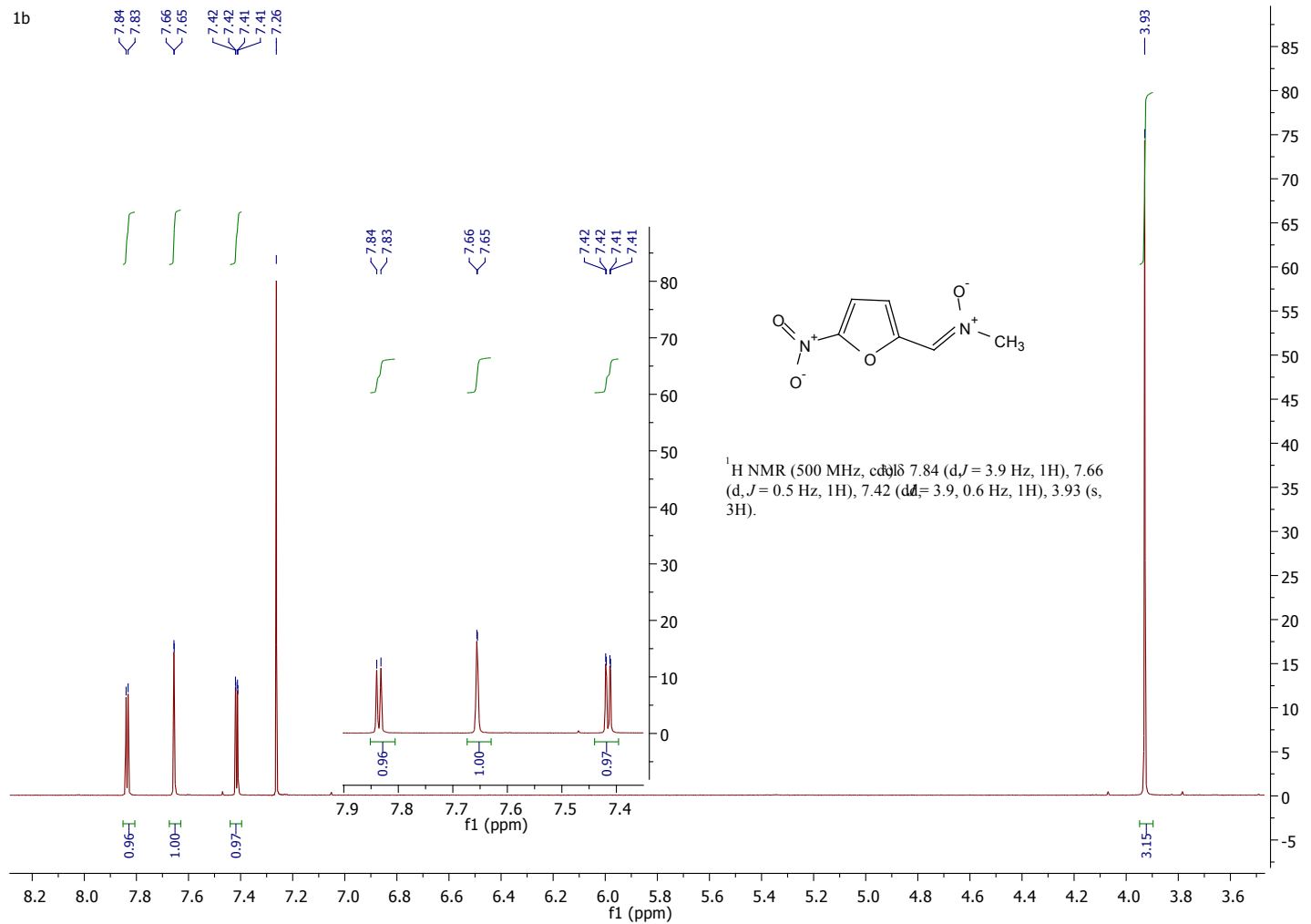


2. ${ }^{13} \mathrm{C} \mathrm{NMR}\left(126 \mathrm{Mhz}, \mathrm{CDCl}_{3}\right) \mathbf{1 b}$.

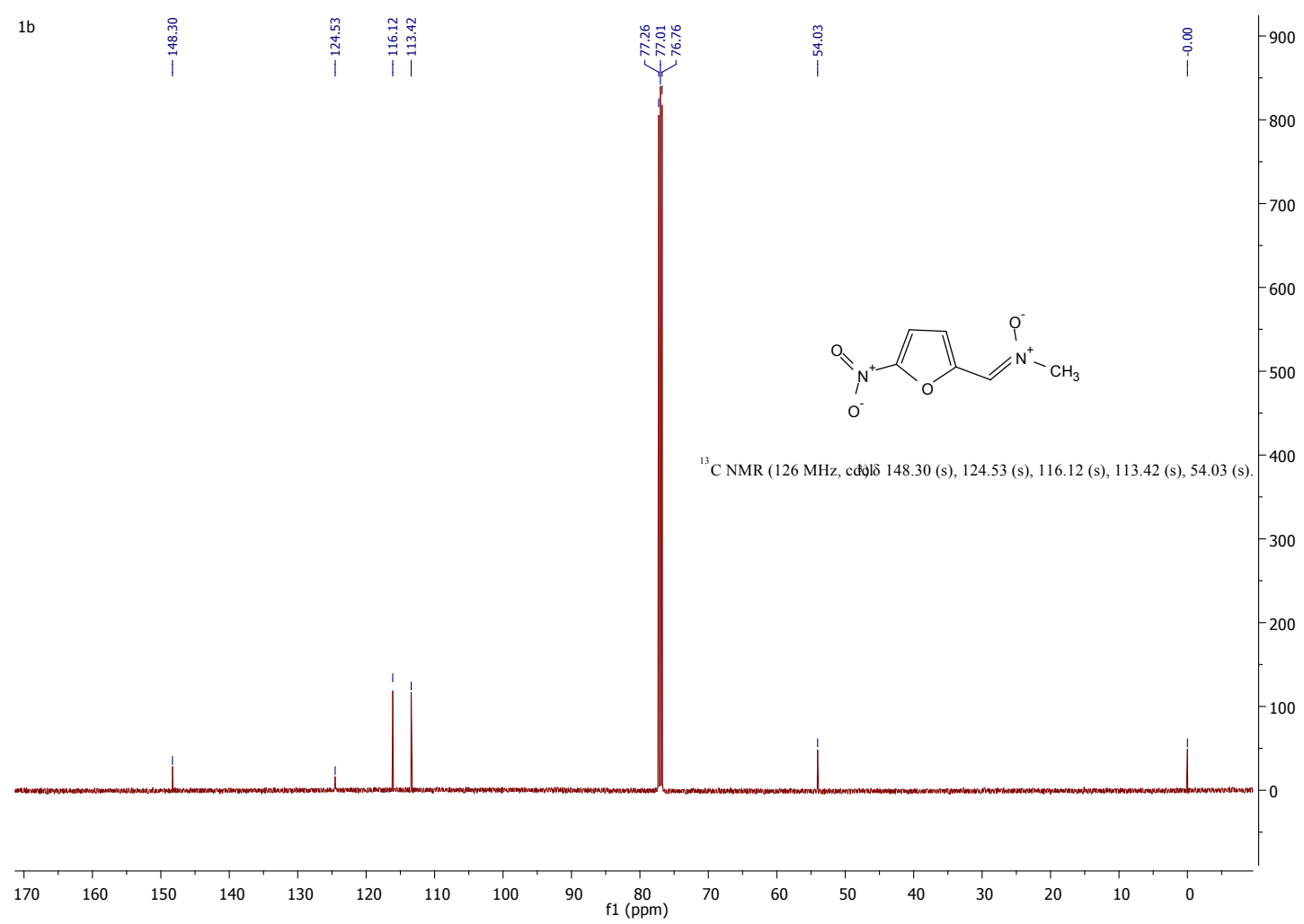

3. COSY NMR (500 Mhz, $\left.\mathrm{CDCl}_{3}\right) \mathbf{1 b}$.

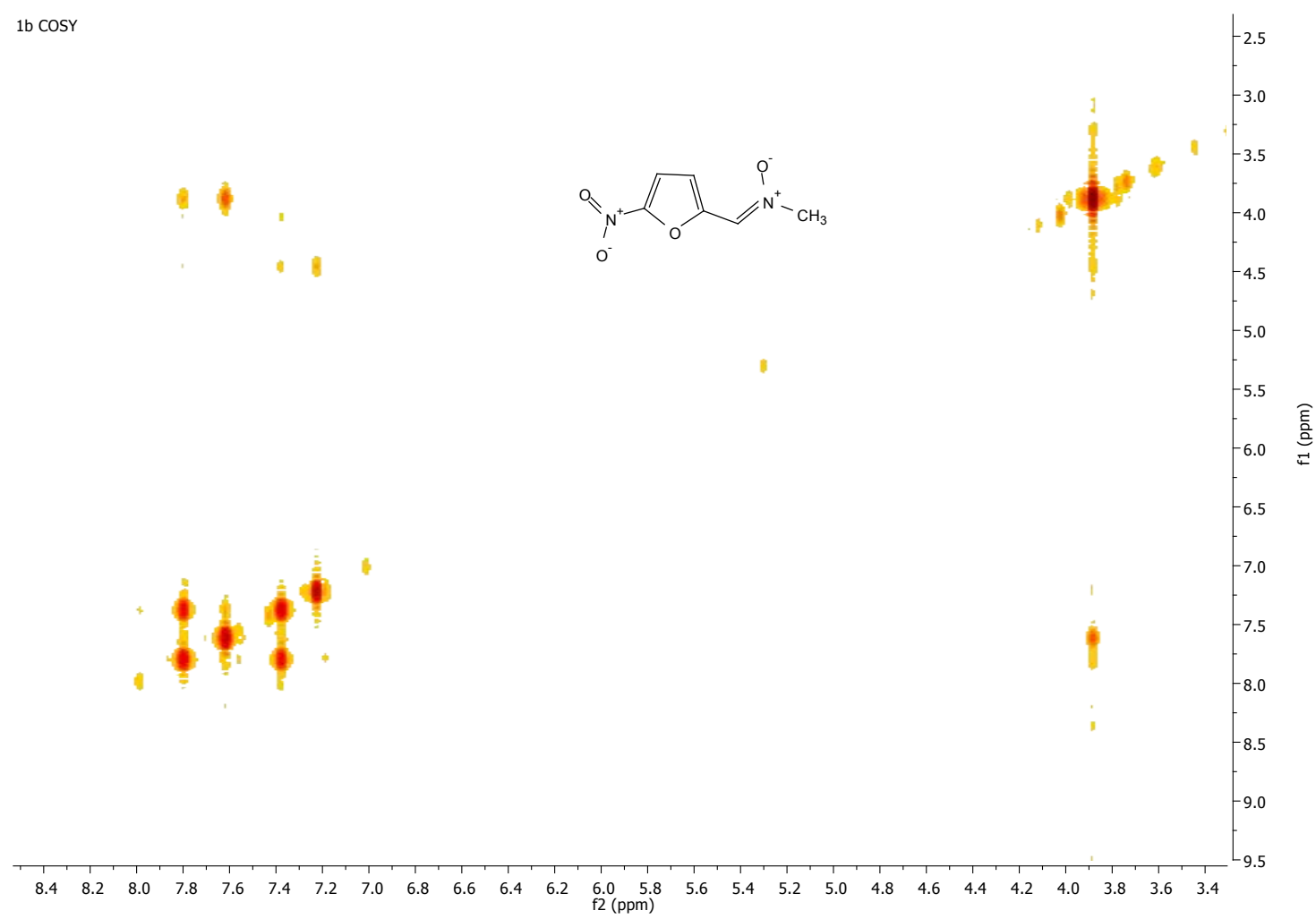


4. HSQC NMR (500 Mhz, $\left.\mathrm{CDCl}_{3}\right) \mathbf{1 b}$

1b HSQC<smiles>C[N+]([O-])=Cc1ccc([N+](=O)[O-])o1</smiles>

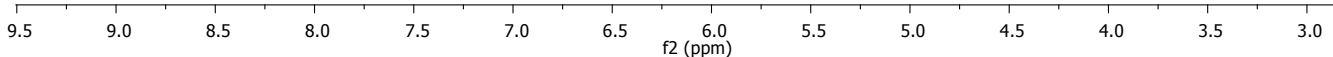

\section{HRMS of $\mathbf{1 b}$.}

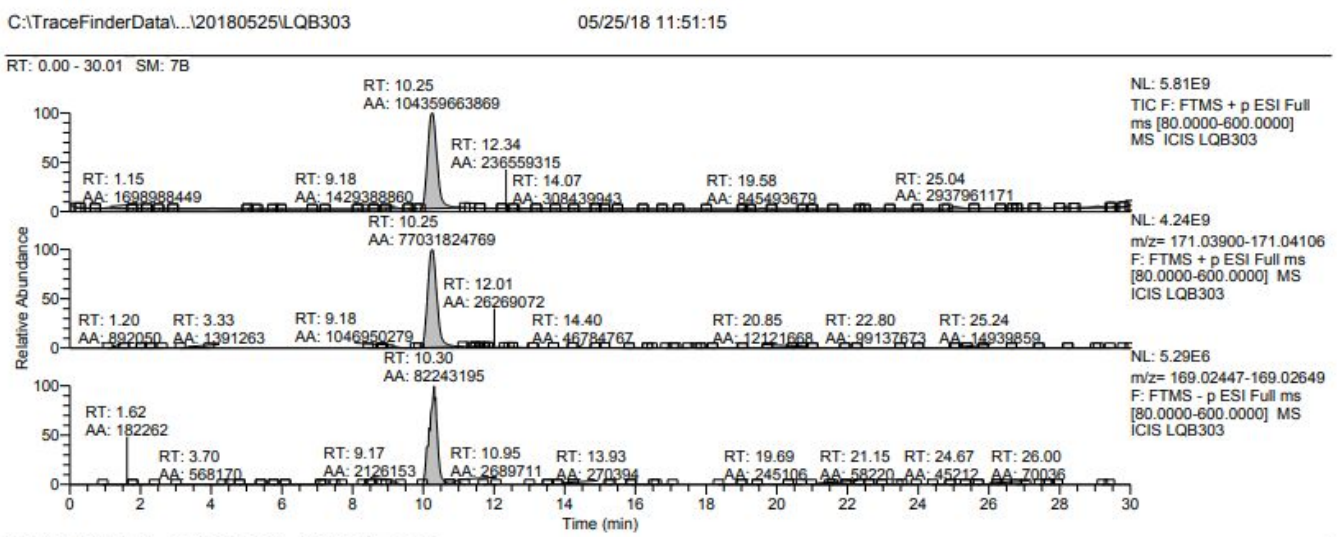

LQB303 \#3161-3257 RT: $10.15-10.41 \quad$ AV: $12 \quad$ NL: 3.39E9
T: FTMS + p ESI Full ms $[80.0000-6000000]$

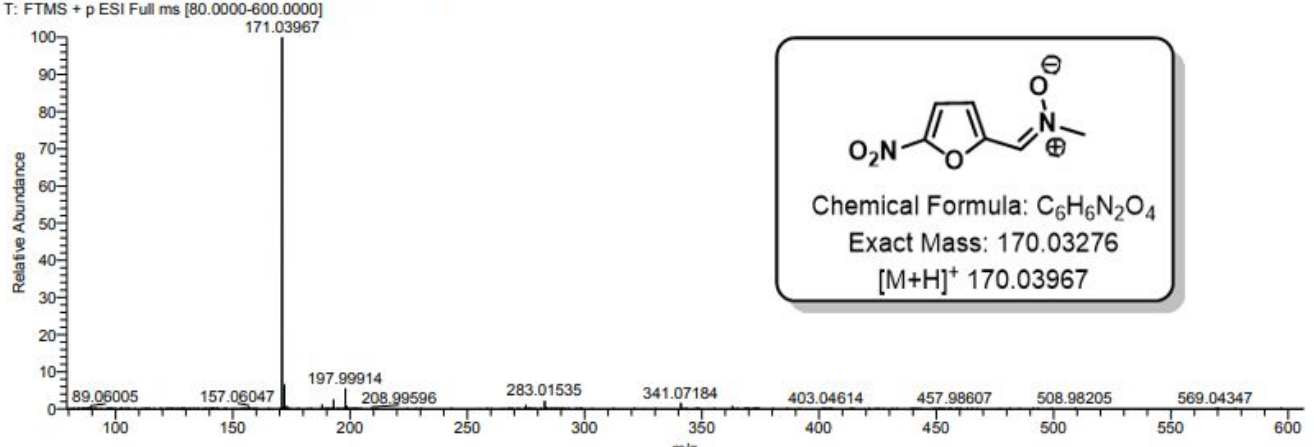


6. Chromatographic purity of $\mathbf{1 b}$ by HPLC

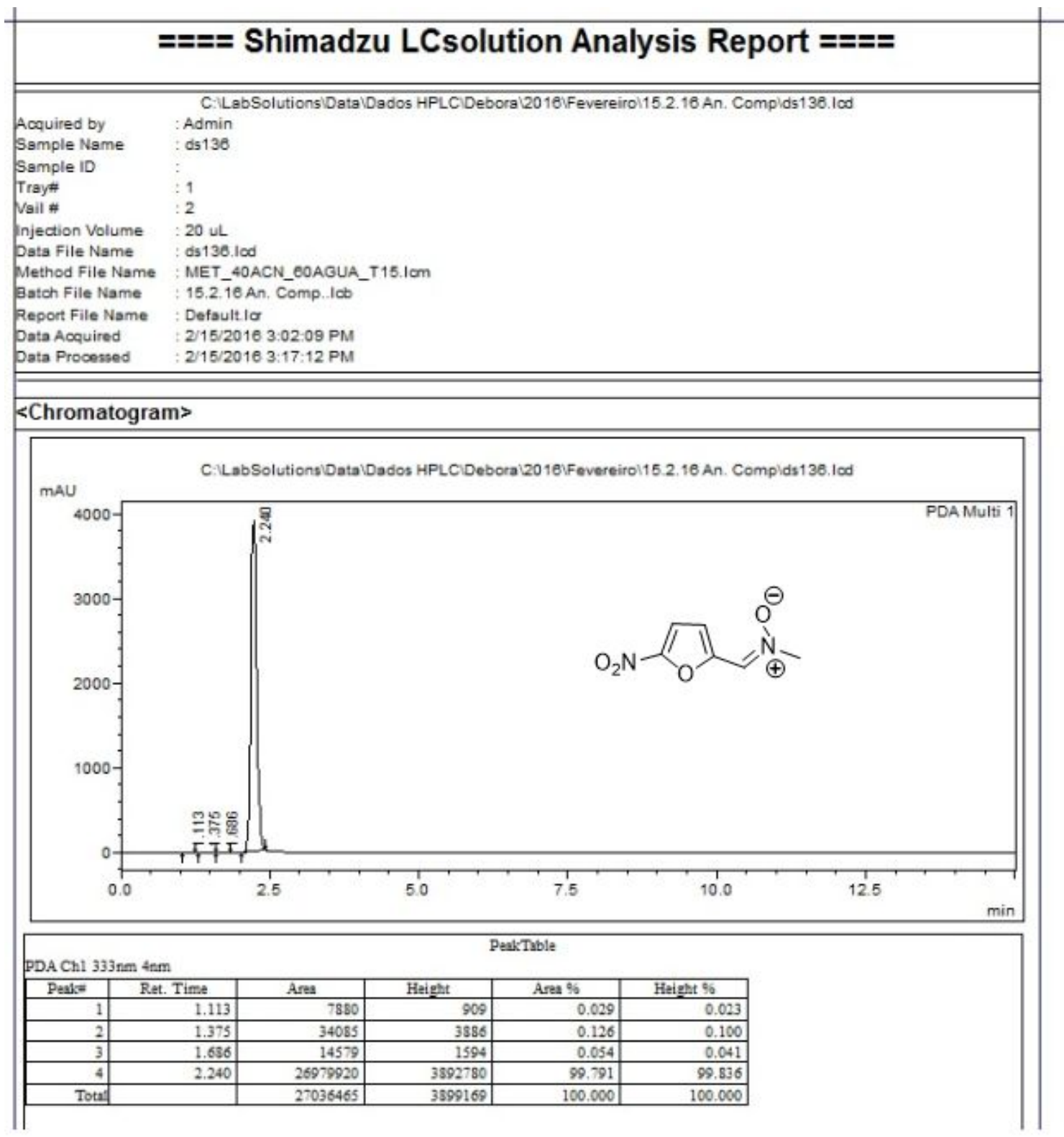


7. ${ }^{1} \mathrm{H}$ NMR (500 Mhz, $\left.\mathrm{CDCl}_{3}\right) \mathbf{2 b}$.

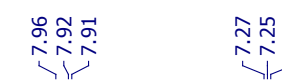

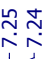
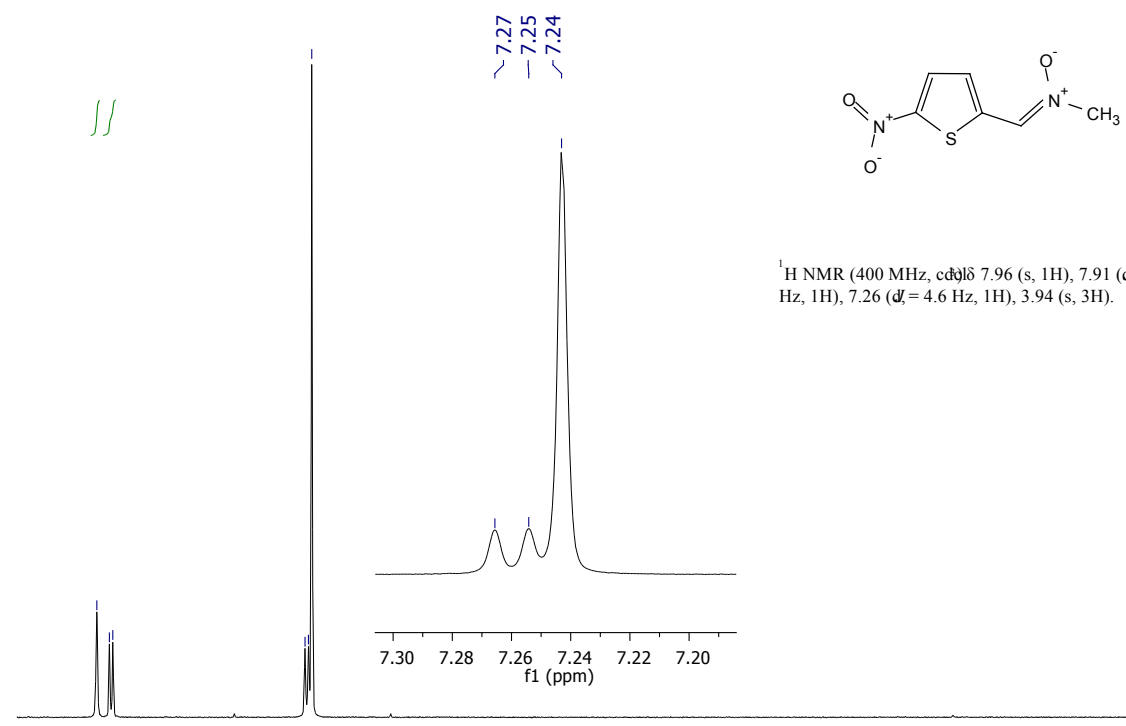

${ }^{1} \mathrm{H}$ NMR (400 MHz, cdoll 7.96 (s, 1H), 7.91 (d, = 4.5 $\mathrm{Hz}, 1 \mathrm{H}), 7.26(\mathrm{~d},=4.6 \mathrm{~Hz}, 1 \mathrm{H}), 3.94(\mathrm{~s}, 3 \mathrm{H})$.

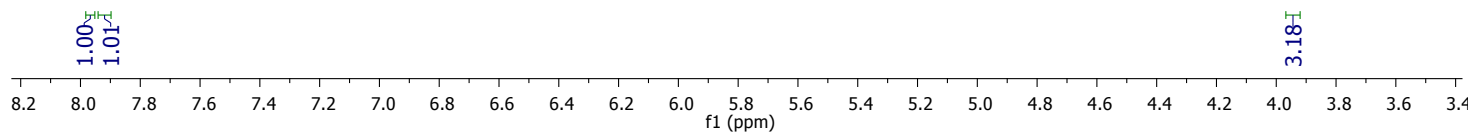

8. $\left.{ }^{13} \mathrm{C} \mathrm{NMR} \mathrm{(126} \mathrm{Mhz,} \mathrm{CDCl}_{3}\right) \mathbf{2 b}$.

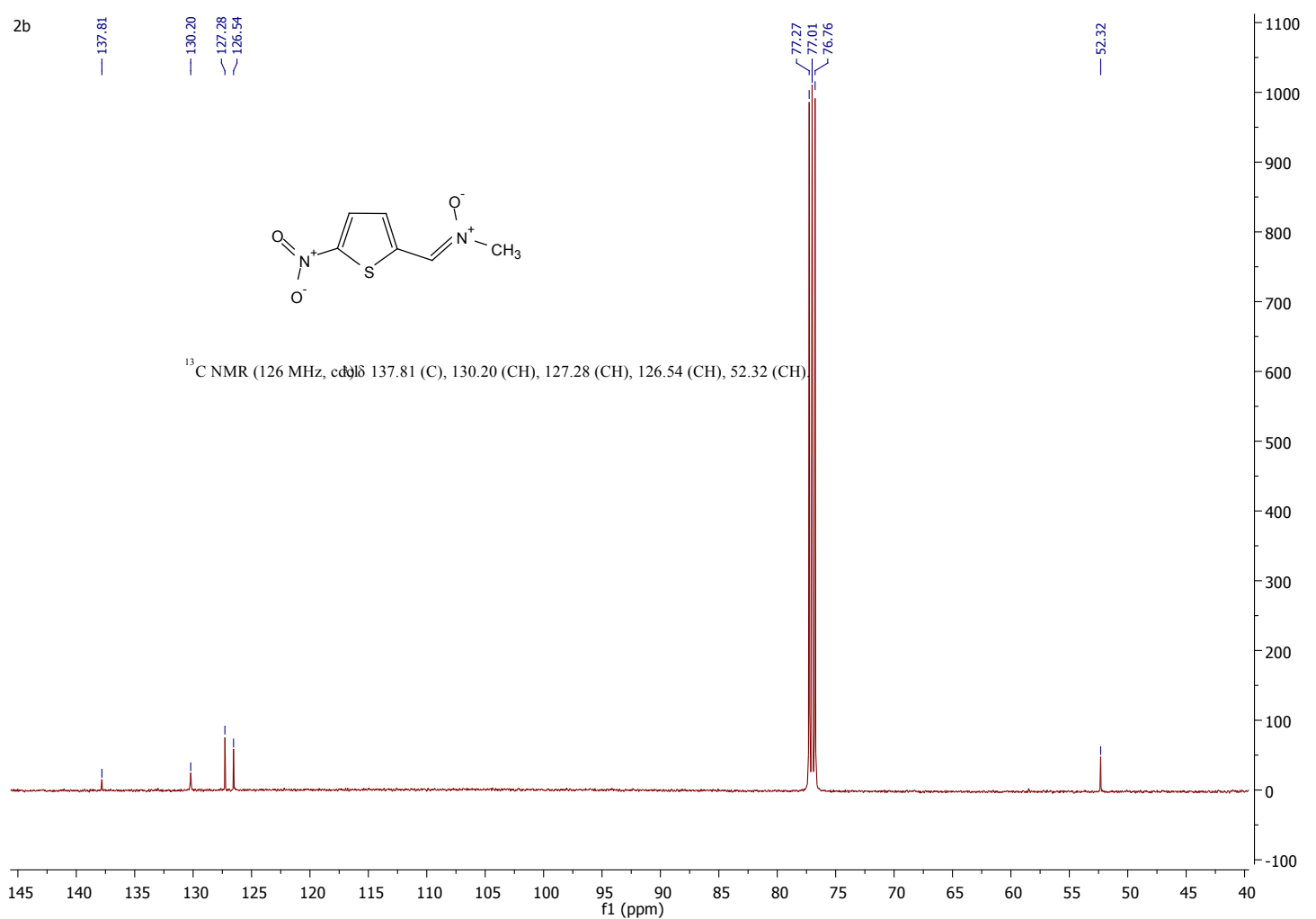


9. COSY NMR (500 Mhz, $\left.\mathrm{CDCl}_{3}\right) \mathbf{2 b}$.

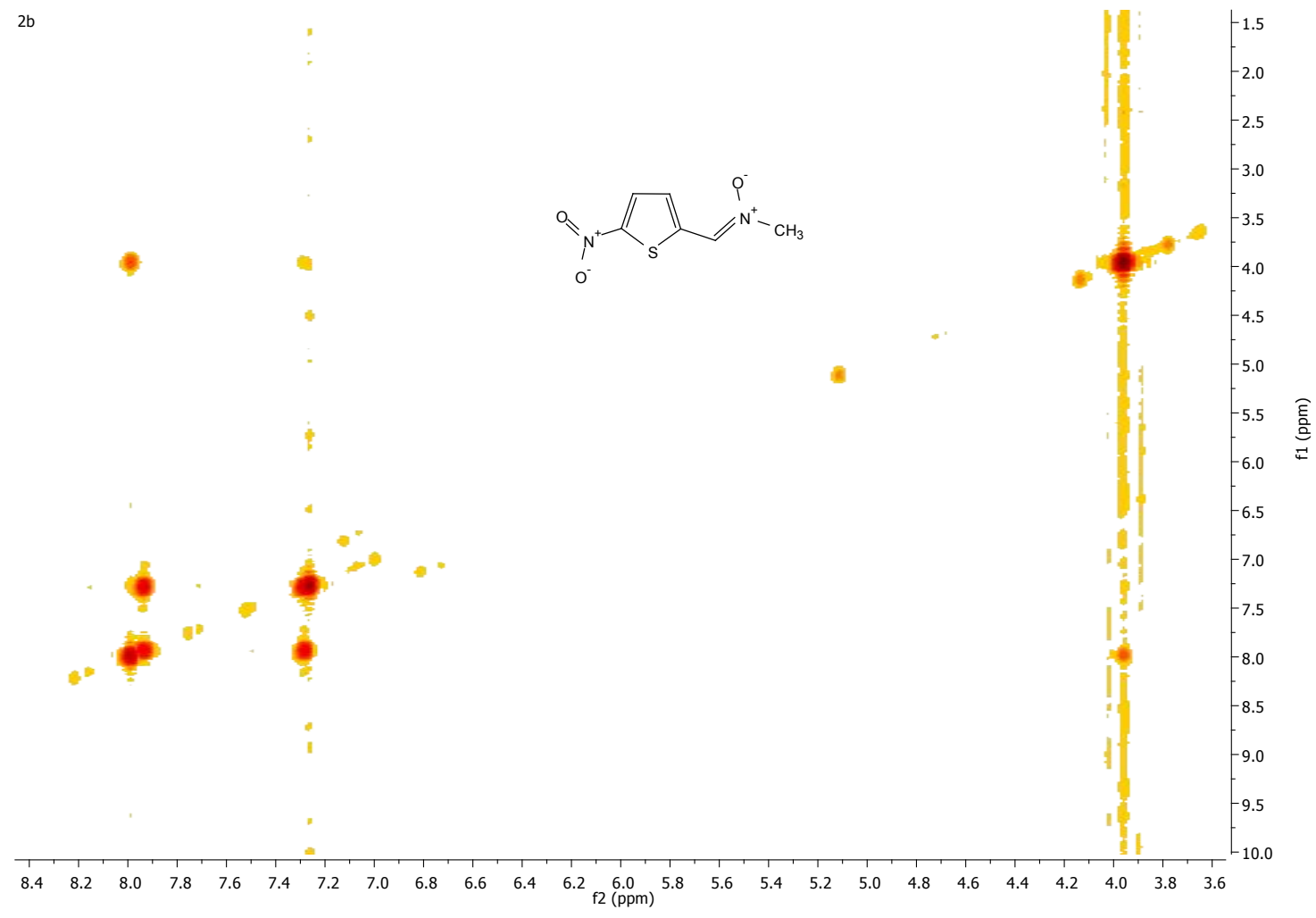

10. HSQC NMR (500 Mhz, $\mathrm{CDCl}_{3}$ ) do $\mathbf{2 b}$.

$2 b$

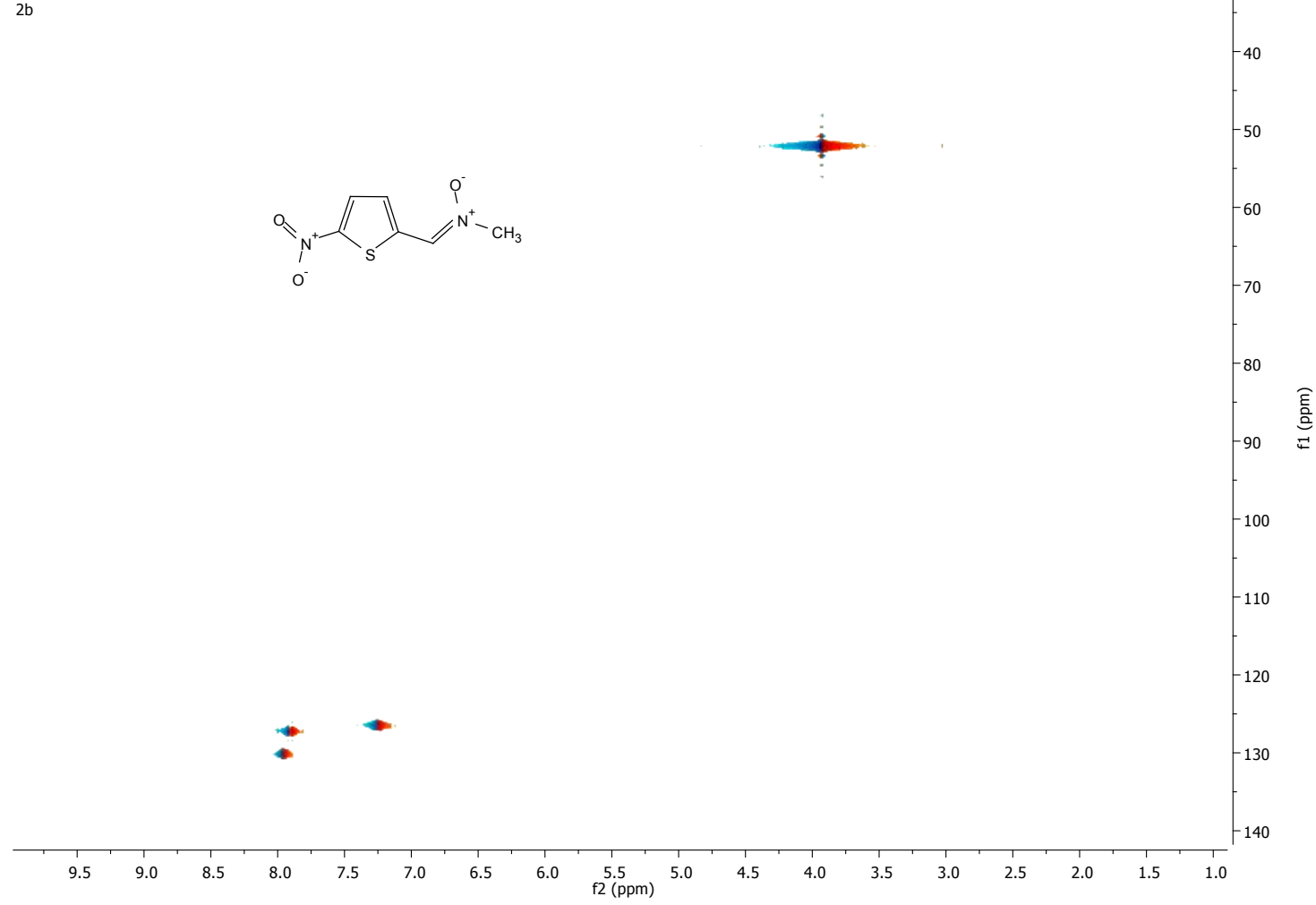


11. HRMS $2 \mathbf{b}$

C:ITraceFinderDatal...120180525LQB304

05/25/18 12:23:43

RT: $0.00-30.01$ SM: 78

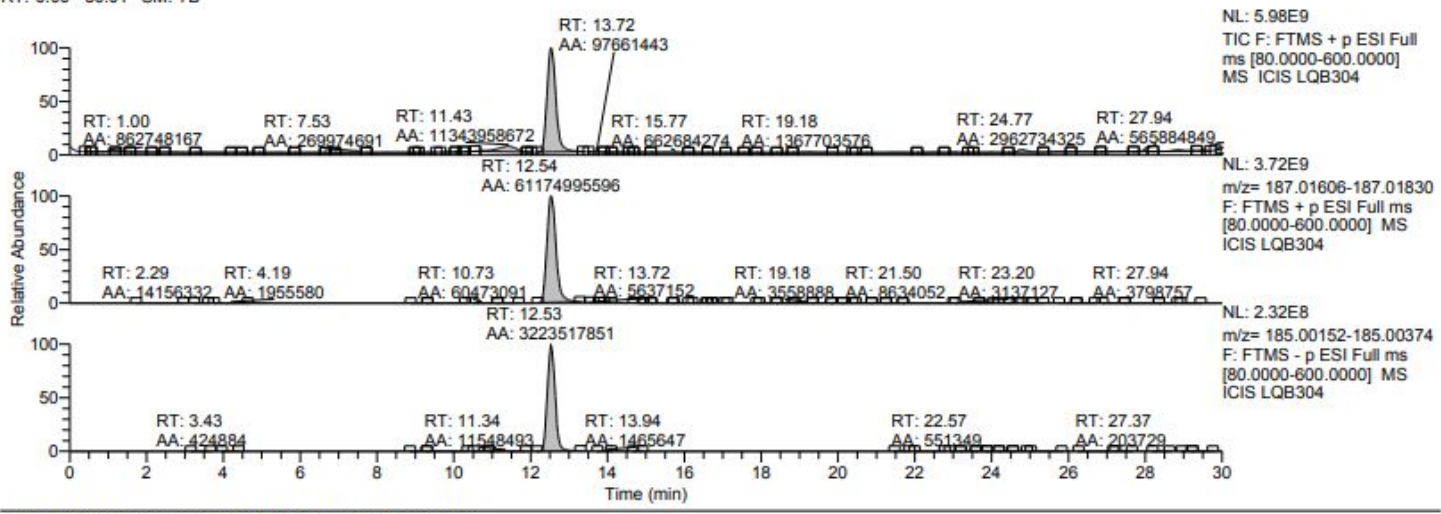

T: FTMS + P ESIF F RT: 12.42-12.68 AV: 12 NL: 2.84E9

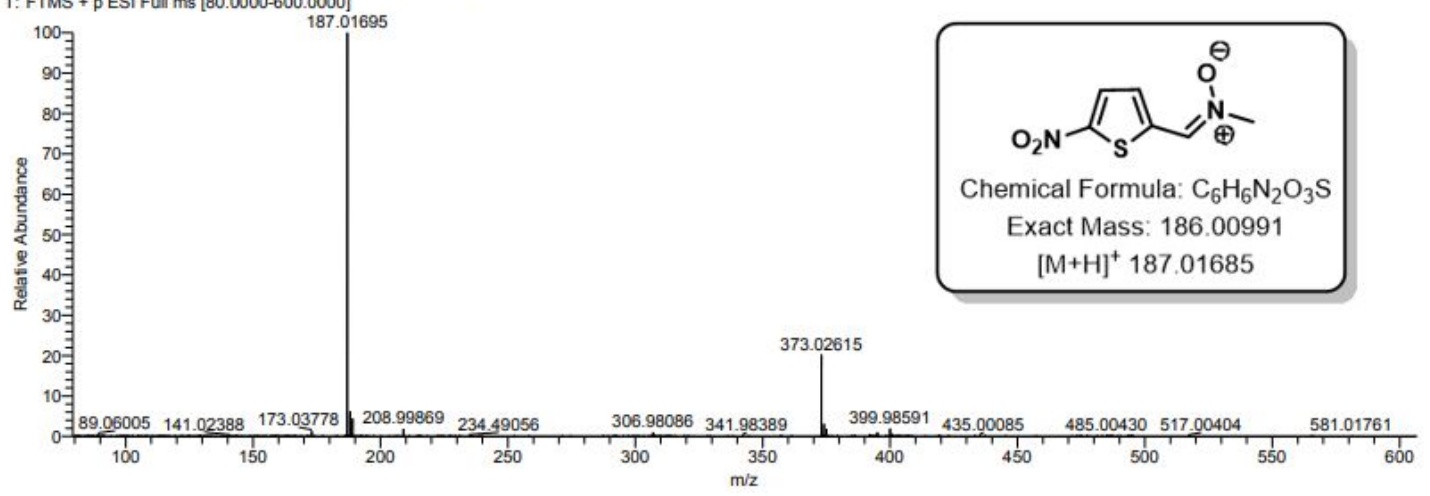


12. Chromatographic purity of $\mathbf{2} \mathbf{b}$ by HPLC

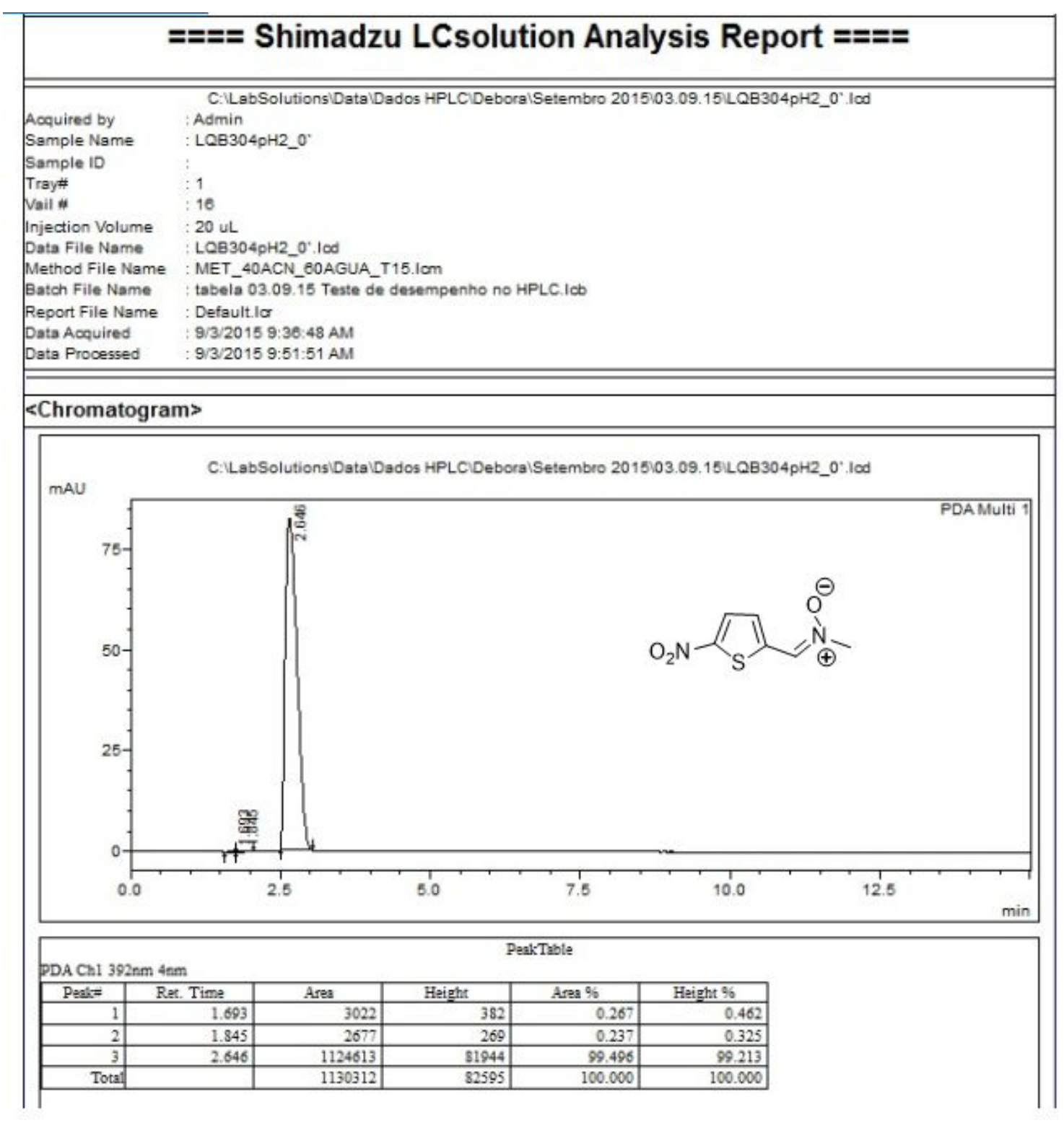


13. ${ }^{1} \mathrm{H}$ NMR (500 Mhz, $\left.\mathrm{CDCl}_{3}\right)$ 1a

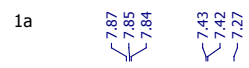

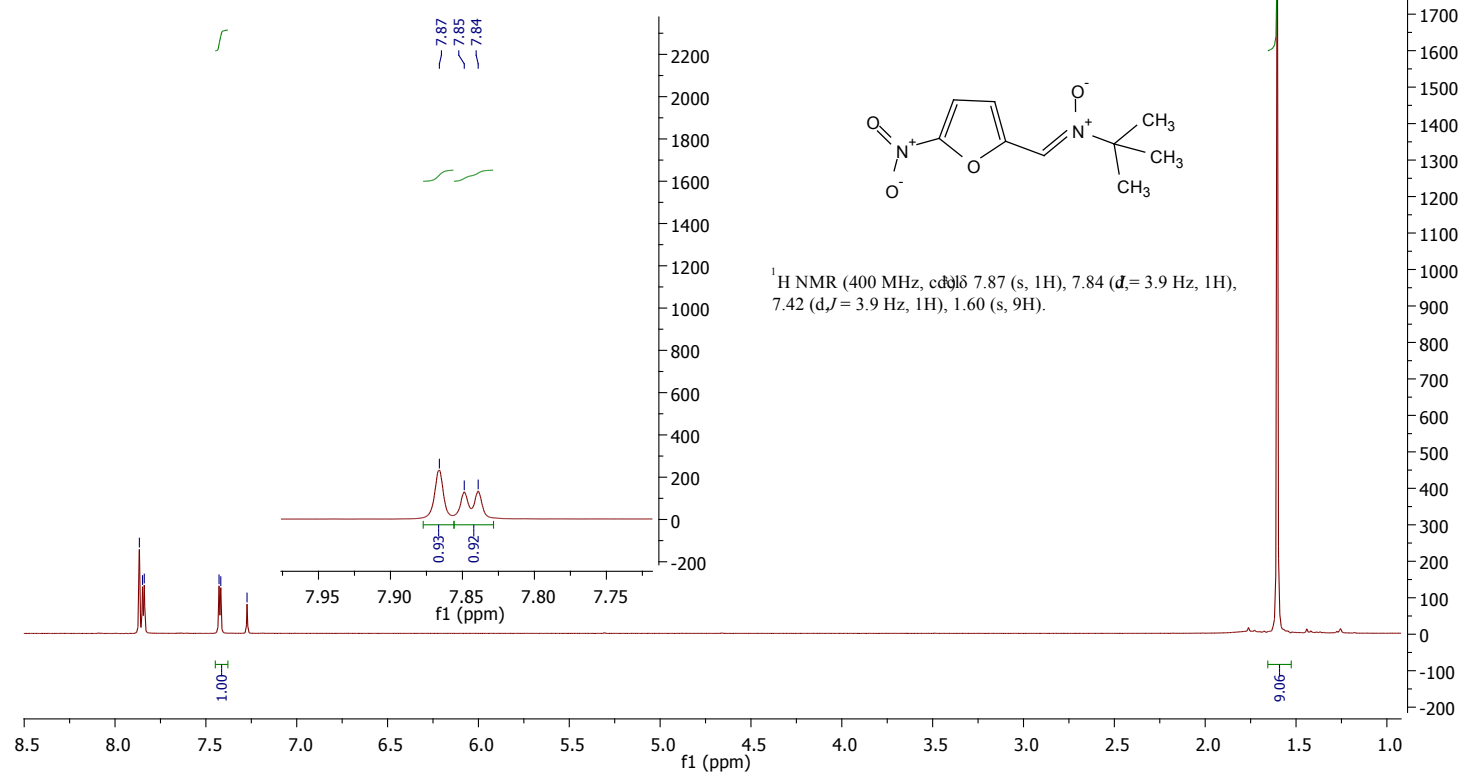

14. ${ }^{13} \mathrm{C}$ NMR (126 Mhz, $\left.\mathrm{CDCl}_{3}\right)$ 1a

1a 青寺

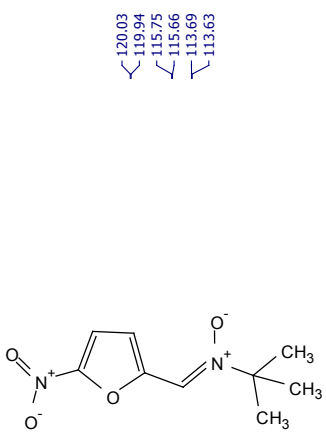

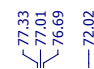

CNMR (101 MHz, cdoll 151.11 (CH), $149.44(\mathrm{CH}), 119.99(\mathrm{t}, 8.5 \mathrm{~Hz})$, $115.71(\mathrm{~d} J=8.7 \mathrm{~Hz}), 113.66(\mathrm{~d}=6.3 \mathrm{~Hz}), 72.02(\mathrm{~s}), 28.03(\mathrm{~s})$

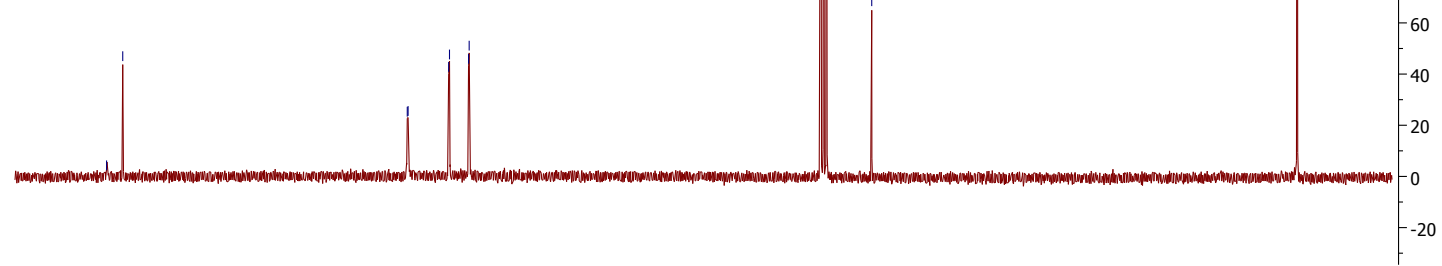

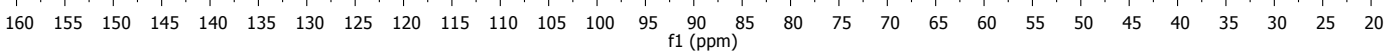


15. COSY NMR (500 Mhz, $\left.\mathrm{CDCl}_{3}\right)$ 1a

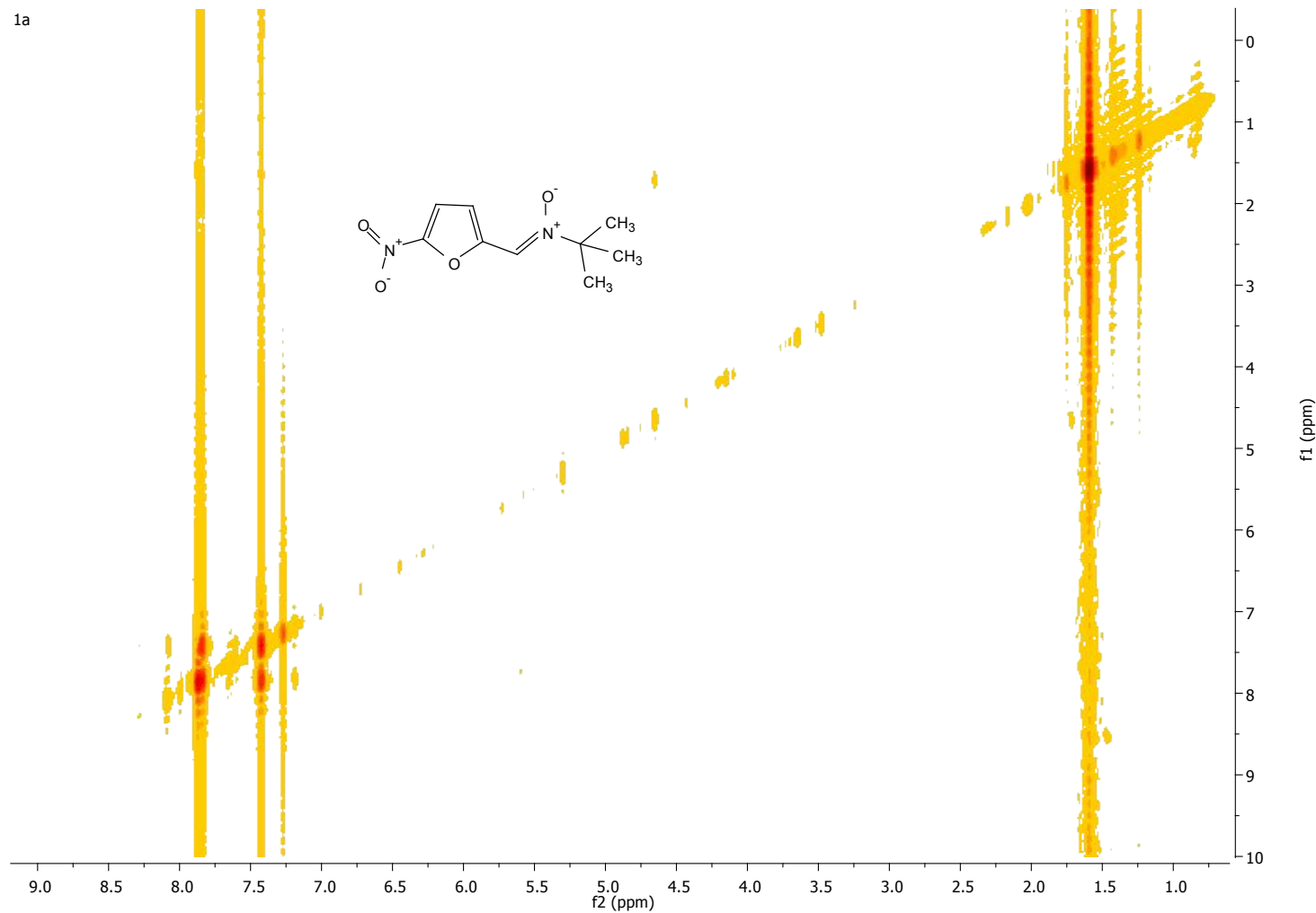

16. HRMS 1a

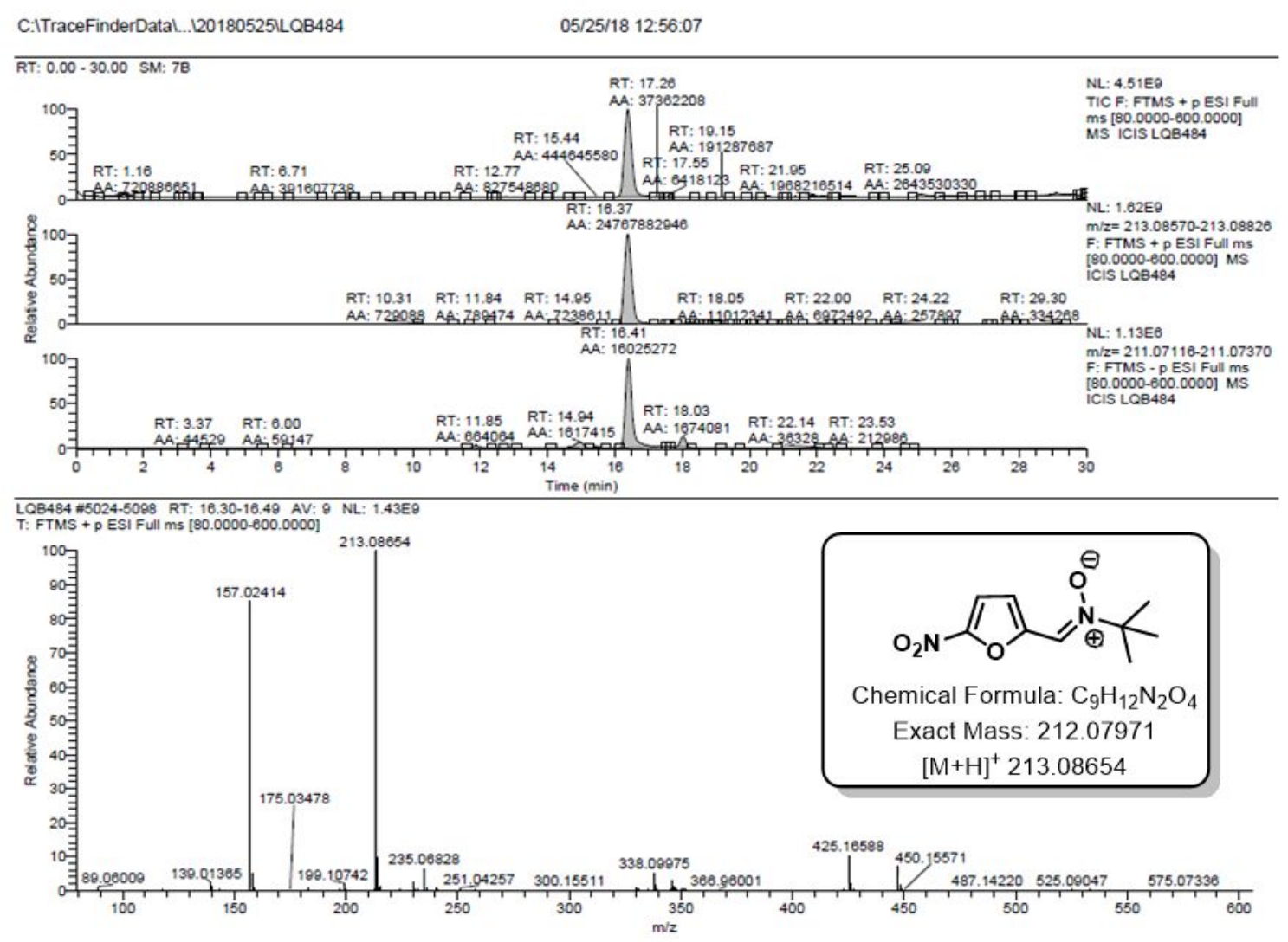


17. Chromatographic purity of $\mathbf{1 a}$ by HPLC

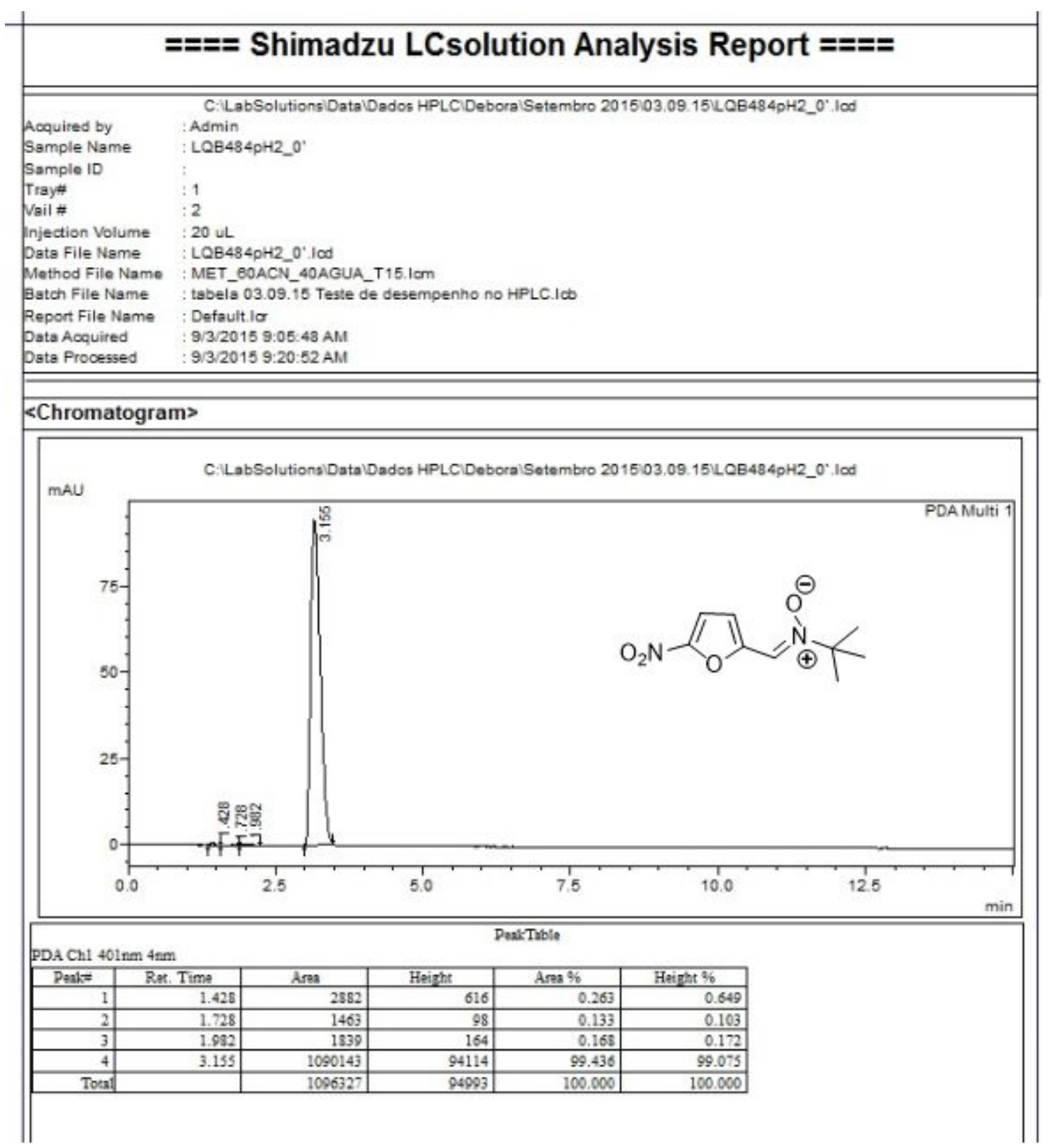


18. ${ }^{1} \mathrm{H}$ NMR (500 Mhz, $\left.\mathrm{CDCl}_{3}\right)$ 2a

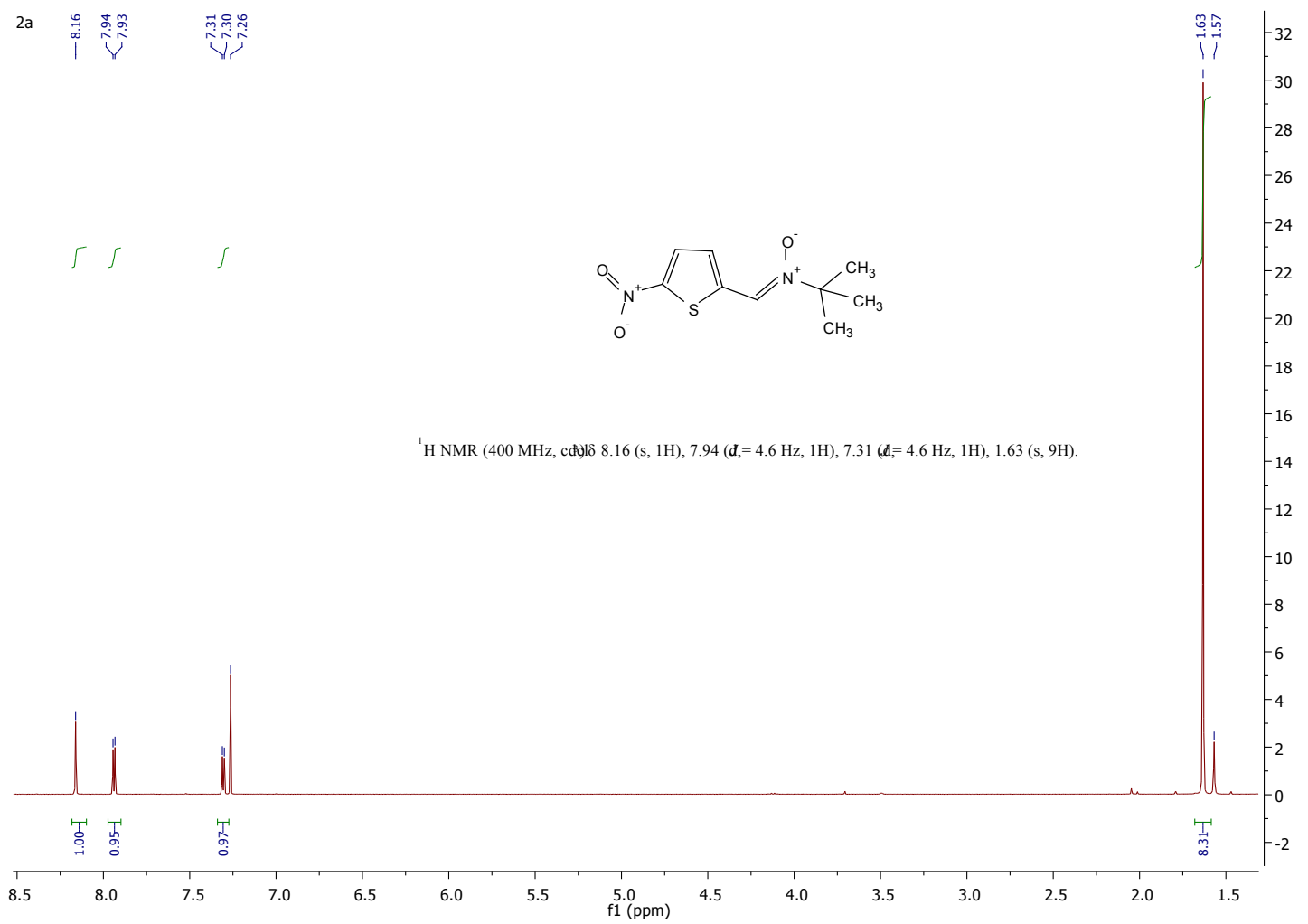

19. $\left.{ }^{13} \mathrm{C} \mathrm{NMR} \mathrm{(126} \mathrm{Mhz,} \mathrm{CDCl}_{3}\right)$ 2a

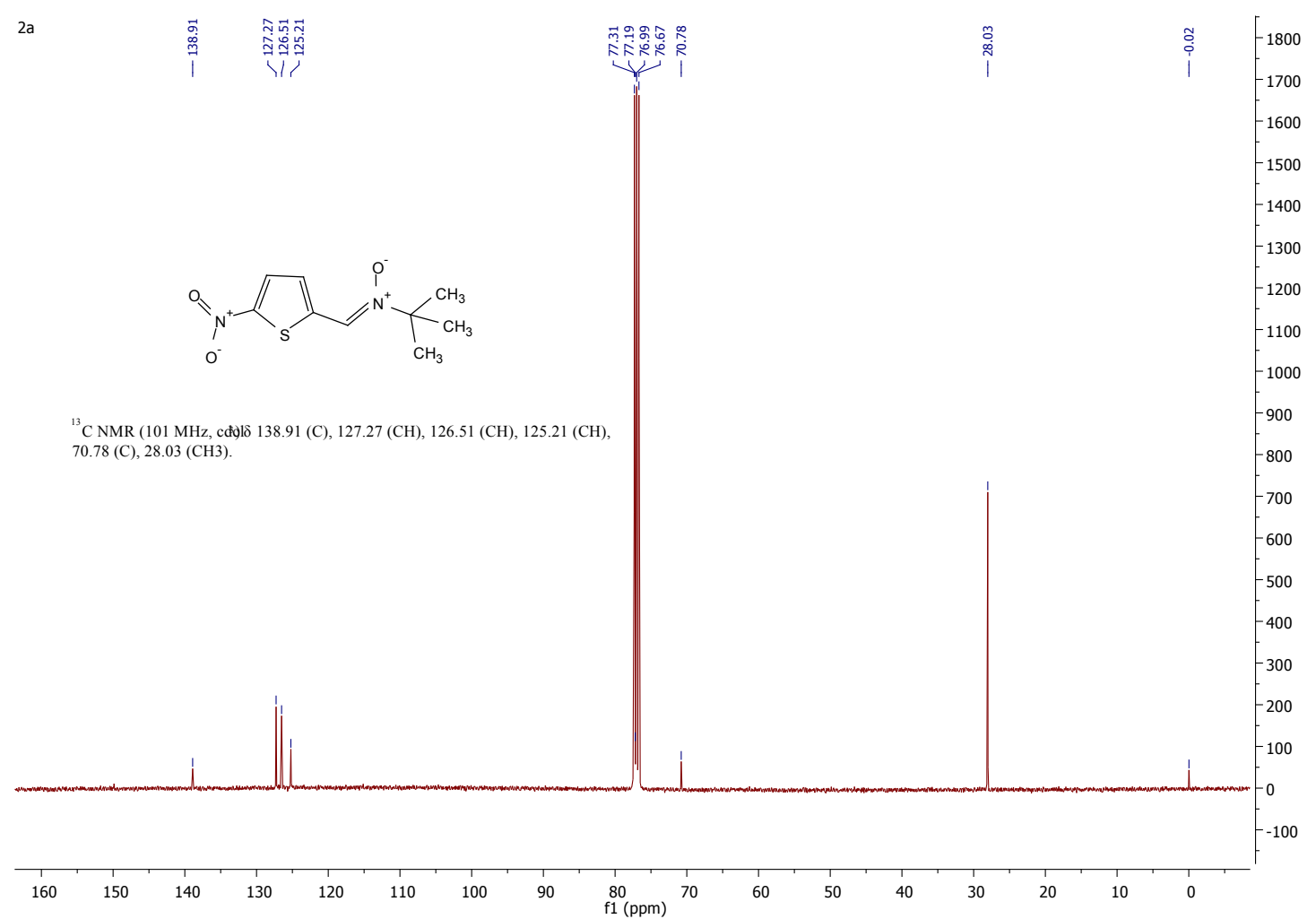


20. COSY NMR (500 Mhz, $\left.\mathrm{CDCl}_{3}\right)$ 2a

$2 a$

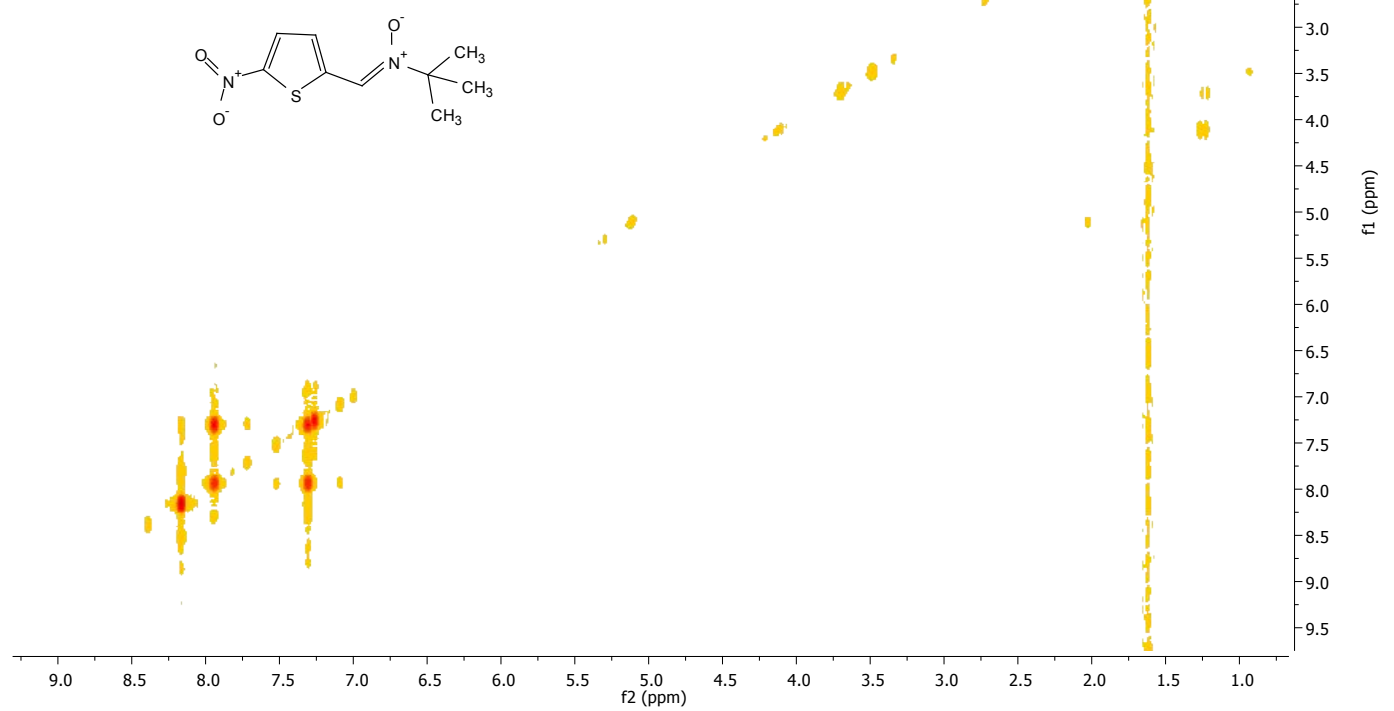

\section{HRMS 2a}

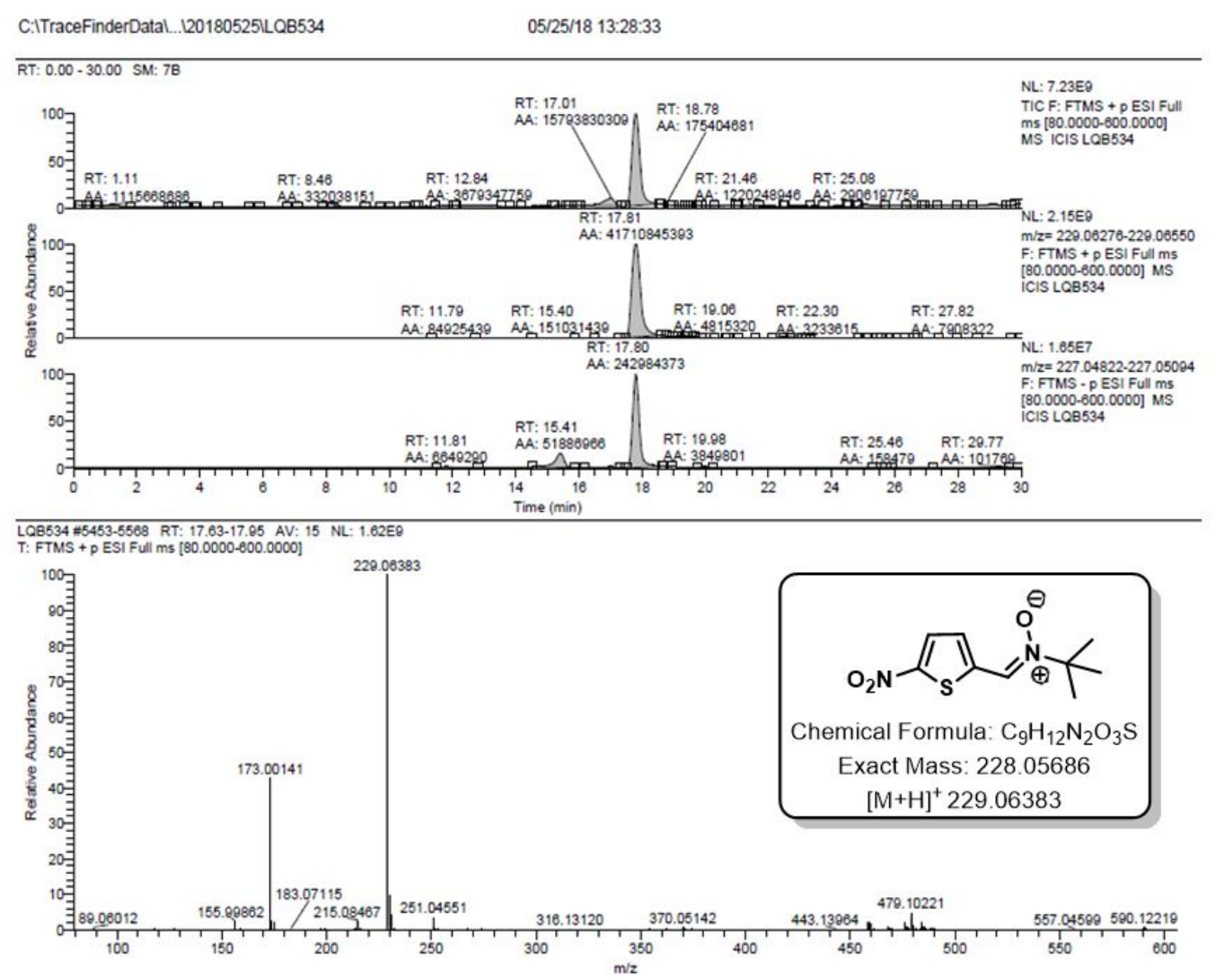


22. Chromatographic purity of $\mathbf{2 a}$ by HPLC

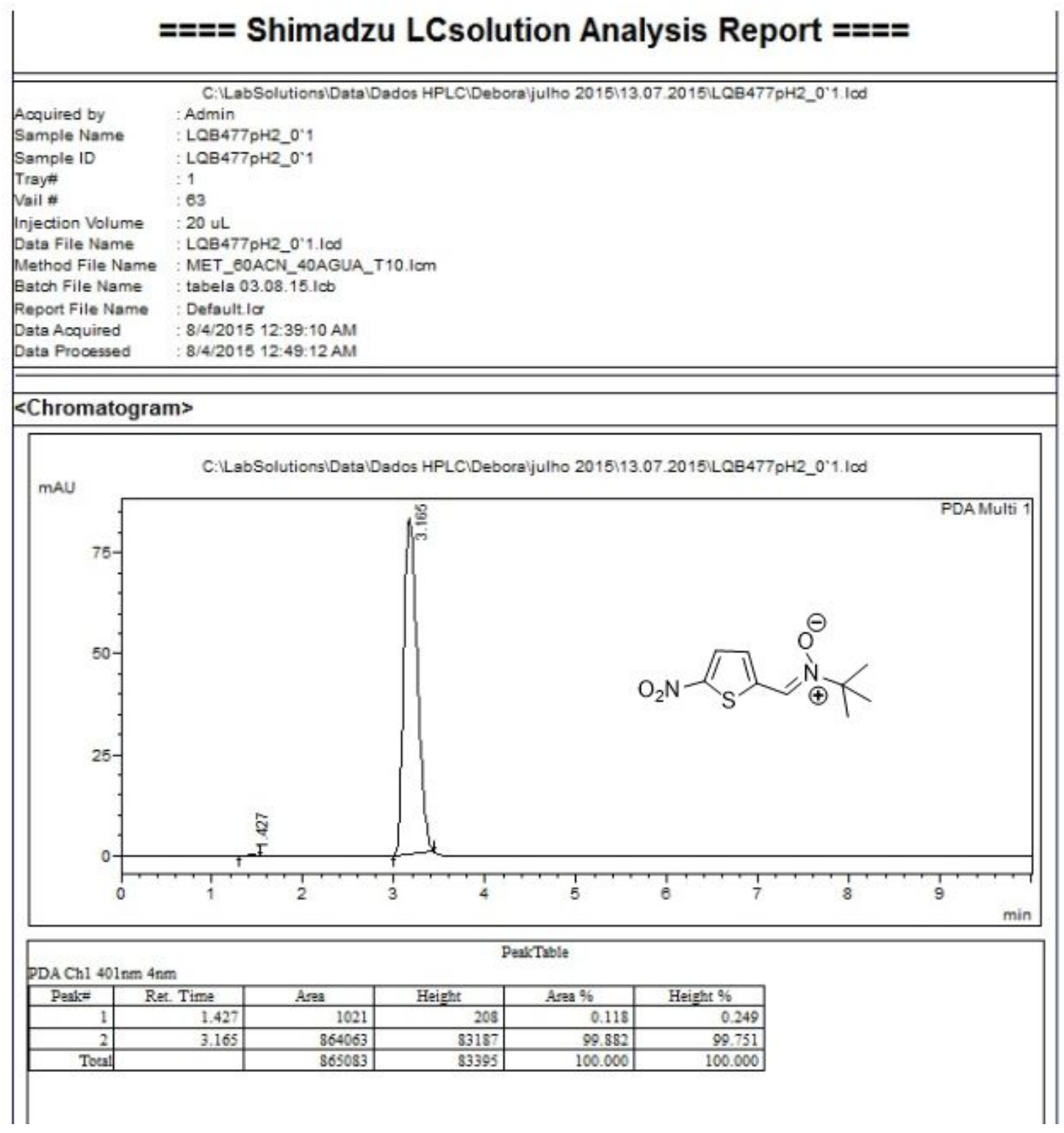


23. ${ }^{1} \mathrm{H}$ NMR (500 Mhz, $\left.\mathrm{CDCl}_{3}\right)$ 1c

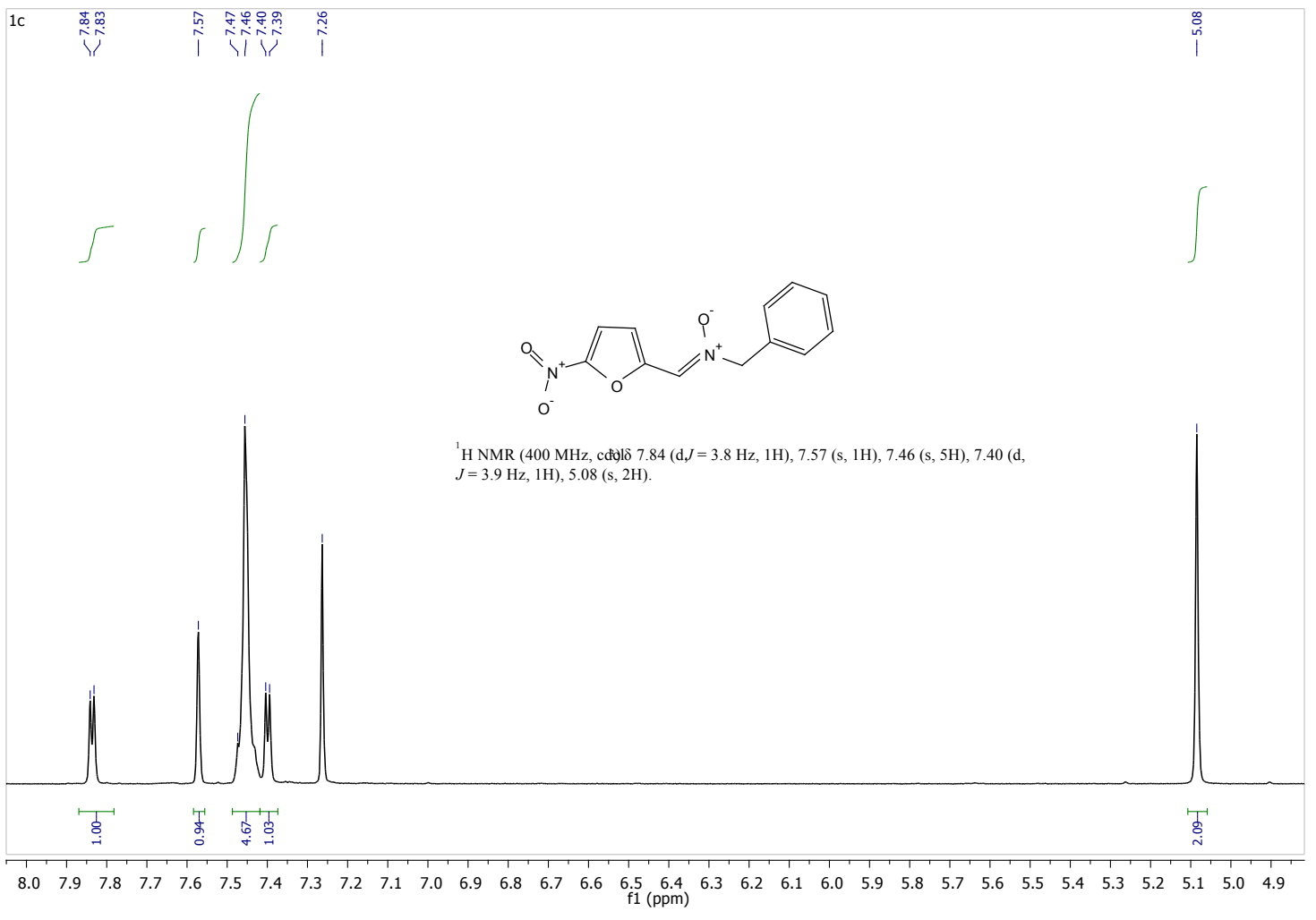

S23 
24. Chromatographic purity by HPLC and HRMS of 1c

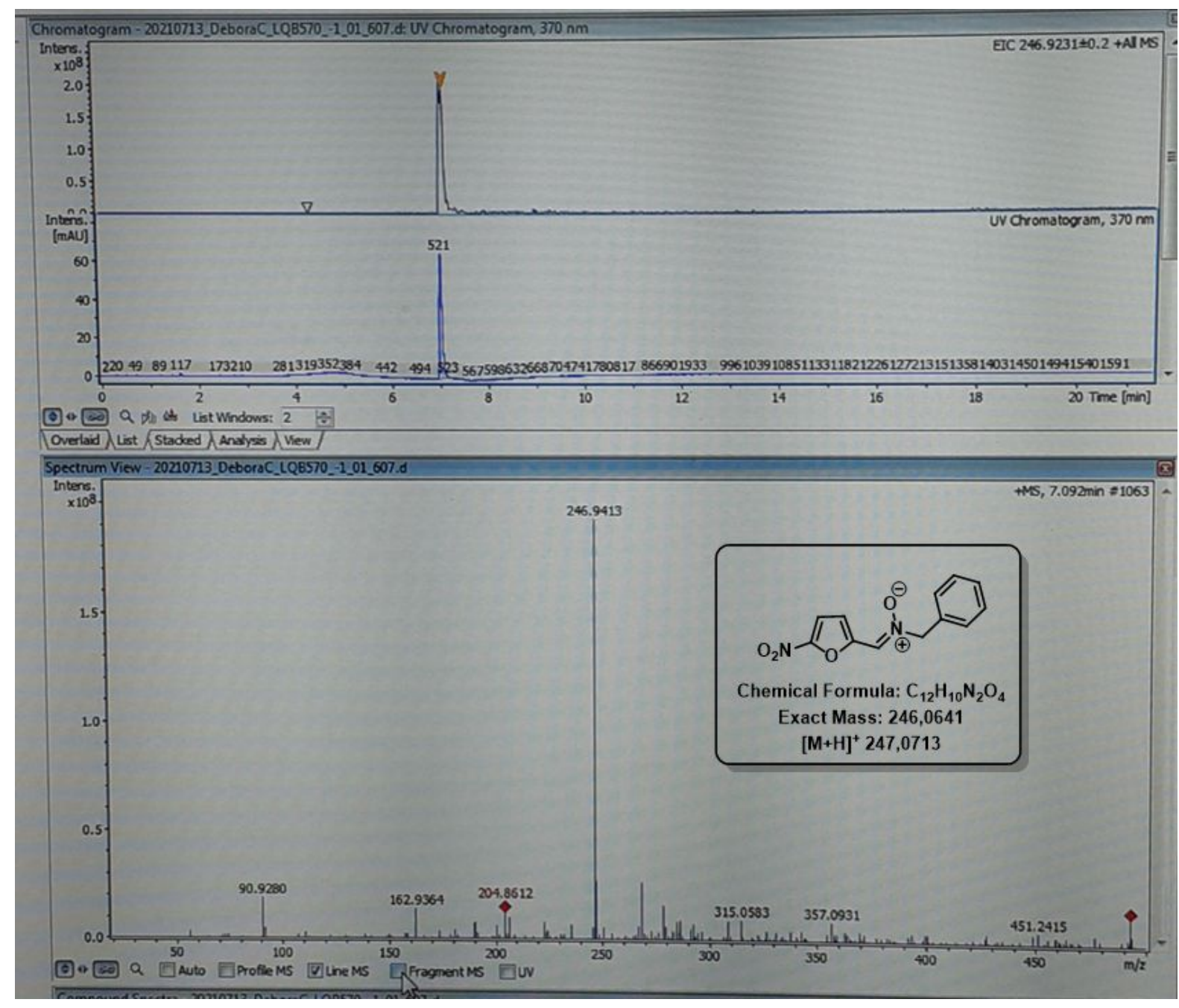


25. ${ }^{1} \mathrm{H}$ NMR (500 Mhz, $\left.\mathrm{CDCl}_{3}\right)$ 2c

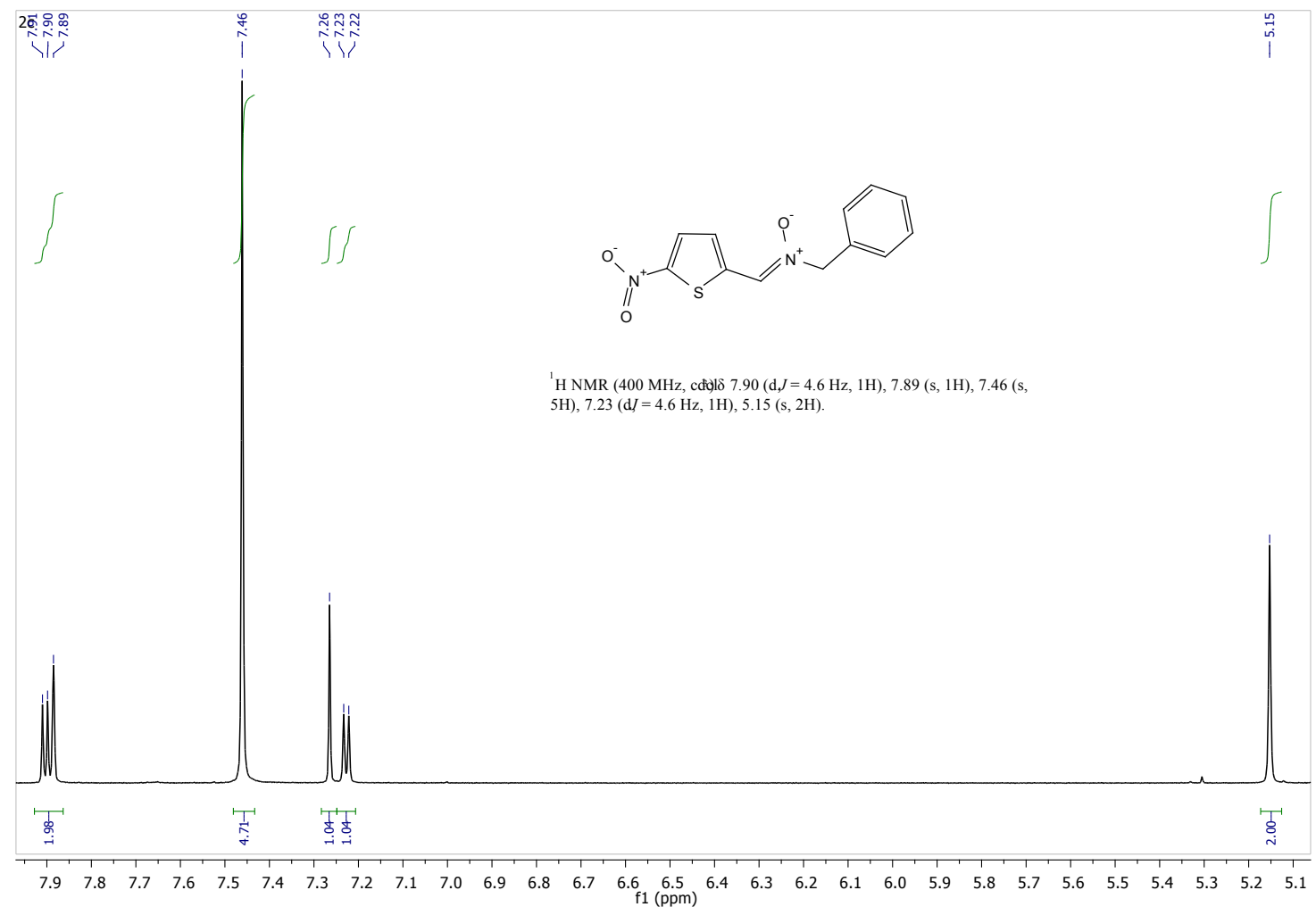




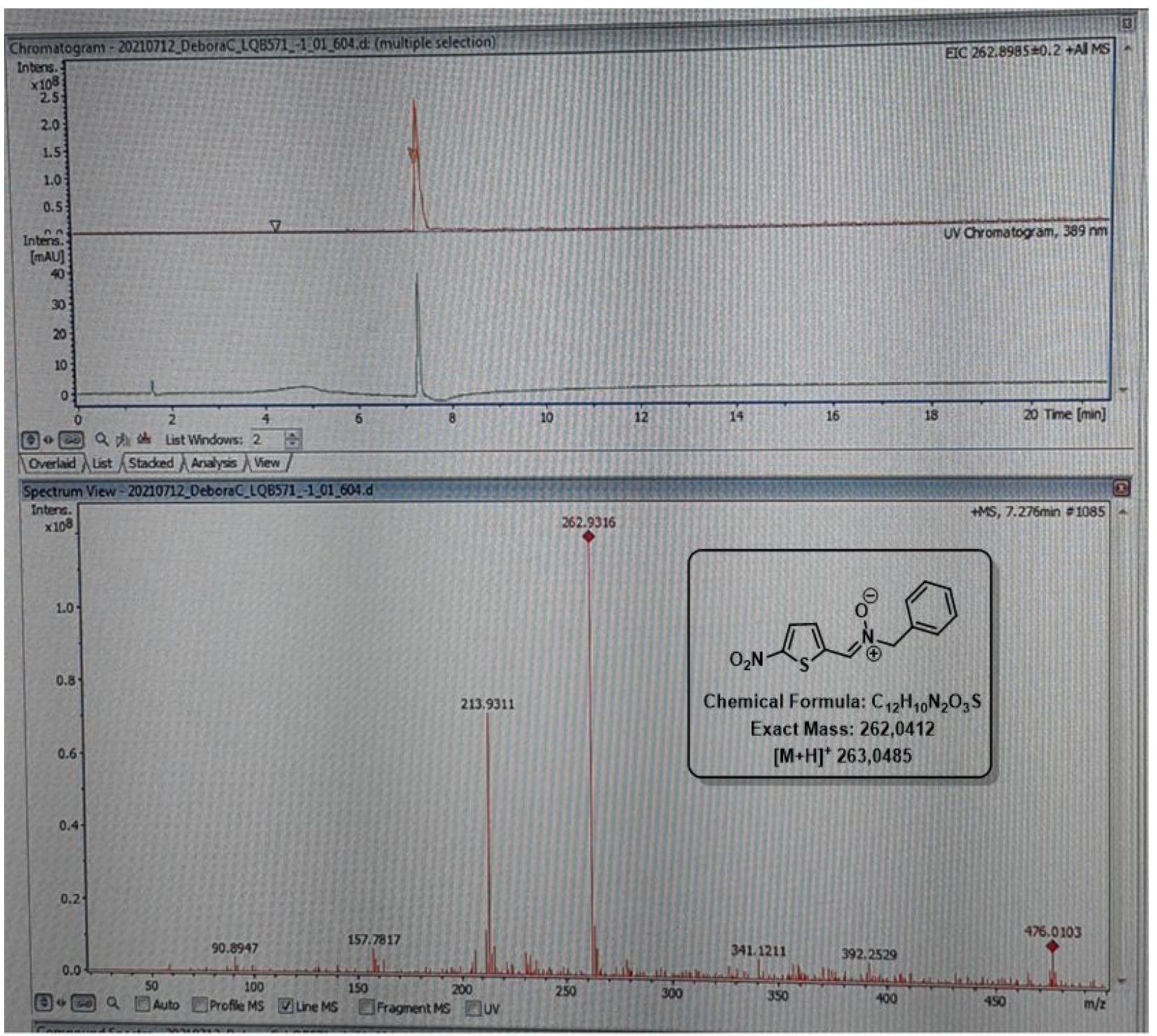

\section{References}

(1) Kakemi, K.; Sezaki, H.; Fujioka, H. Biopharmaceutical Studies on Nitrofuran Derivatives. Intestinal Absorption of Nitrofuran Derivatives. Biopharmaceutical studies on nitrofuran derivatives. Intestinal absorption of nitrofuran derivatives. Yakuzaigaku. 1967, 27, 4, 301304.

(2) Wyllie, S.; Patterson, S.; Fairlamb, A. H. Assessing the Essentiality of Leishmania Donovani Nitroreductase and Its Role in Nitro Drug Activation. Antimicrob. Agents Chemother. 2013, 57, 2, 901-906. https://doi.org/10.1128/AAC.01788-12.

(3) Wyllie, S.; Roberts, A. J.; Norval, S.; Patterson, S.; Foth, B. J.; Berriman, M.; Read, K. D.; Fairlamb, A. H. Activation of Bicyclic Nitro-Drugs by a Novel Nitroreductase (NTR2) in Leishmania. PLoS Pathog 2016, 12, 11, e1005971. https://doi.org/10.1371/journal.ppat.1005971.

(4) da Cunha-Júnior, E. F.; Pacienza-Lima, W.; Ribeiro, G. A.; Netto, C. D.; do CantoCavalheiro, M. M.; da Silva, A. J. M.; Costa, P. R. R.; Rossi-Bergmann, B.; Torres-Santos, E. C. Effectiveness of the Local or Oral Delivery of the Novel Naphthopterocarpanquinone 
LQB-118 against Cutaneous Leishmaniasis. J. Antimicrob. Chemother. 2011, 66, 7, 15551559. https://doi.org/10.1093/jac/dkr158.

(5) Konsoula, R.; Jung, M. In Vitro Plasma Stability, Permeability and Solubility of Mercaptoacetamide Histone Deacetylase Inhibitors. International Journal of Pharmaceutics 2008, 361, 19-25. https://doi.org/10.1016/j.ijpharm.2008.05.001.

(6) Cunha-Júnior, E. F.; Martins, T. M.; Canto-Cavalheiro, M. M.; Marques, P. R.; Portari, E. A.; Coelho, M. G. P.; Netto, C. D.; Costa, P. R. R.; Sabino, K. C. de C.; Torres-Santos, E. C. Preclinical Studies Evaluating Subacute Toxicity and Therapeutic Efficacy of LQB-118 in Experimental Visceral Leishmaniasis. Antimicrob Agents Chemother 2016, 60, 6, 3794 3801. https://doi.org/10.1128/AAC.01787-15.

(7) Reagan-Shaw, S.; Nihal, M.; Ahmad, N. Dose Translation from Animal to Human Studies Revisited. FASEB J 2008, 22, 3, 659-661. https://doi.org/10.1096/fj.07-9574LSF.

(8) Rodrigues, D. A.; Ferreira-Silva, G. À.; Ferreira, A. C. S.; Fernandes, R. A.; Kwee, J. K.; Sant'Anna, C. M. R.; Ionta, M.; Fraga, C. A. M. Design, Synthesis, and Pharmacological Evaluation of Novel N-Acylhydrazone Derivatives as Potent Histone Deacetylase 6/8 Dual Inhibitors. $J$ Med Chem 2016, 59, 2, 655-670. https://doi.org/10.1021/acs.jmedchem.5b01525.

(9) Dias, A. G.; Santos, C. E. V.; Cyrino, F. Z. G. A.; Bouskela, E.; Costa, P. R. R. N-tertButyl and N-methyl nitrones derived from aromatic aldehydes inhibit macromolecular permeability increase induced by ischemia/reperfusion in hamsters. Bioorg. Med. Chem. 2009, 17, 3995-3998. 10.1016/j.bmc.2009.04.004. 